\title{
Variability of the meridional overturning circulation at the Greenland- Portugal OVIDE section from 1993 to 2010
}

\author{
Herlé Mercier ${ }^{\mathrm{a}, *}$, Pascale Lherminier ${ }^{\mathrm{b}}$, Artem Sarafanov $^{\mathrm{c}}$, Fabienne Gaillard ${ }^{\mathrm{b}}$, Nathalie Daniault ${ }^{\mathrm{d}}$, \\ Damien Desbruyères ${ }^{a}$, Anastasia Falina $^{c}$, Bruno Ferron $^{a}$, Claire Gourcuff $^{a}$, Thierry Huck ${ }^{a}$, \\ Virginie Thierry ${ }^{\mathrm{b}}$
}

\author{
a CNRS, Laboratoire de Physique des Océans, UMR 6523 CNRS/Ifremer/IRD/UBO, Ifremer Centre de Brest, CS \\ 10070, Plouzané, France \\ ${ }^{\mathrm{b}}$ Ifremer, Laboratoire de Physique des Océans, UMR 6523 CNRS/Ifremer/IRD/UBO, Ifremer Centre de Brest, CS \\ 10070, Plouzané, France \\ ${ }^{c}$ P.P. Shirshov Institute of Oceanology, 36, Nahimovski prospect, Moscow, Russia \\ d UBO, Laboratoire de Physique des Océans, UMR 6523 CNRS/Ifremer/IRD/UBO, 6, avenue le Gorgeu, CS \\ 93837, 29285, Brest Cedex, France
}

\author{
*: Corresponding author : Herlé Mercier, Tel.: +33298224286; fax: +33298224496; \\ email address : Herle.Mercier@ifremer.fr
}

\begin{abstract}
:
The meridional overturning circulation (MOC) in the North Atlantic transports heat from the subtropics to high latitudes and hence plays an important role in the Earth's climate. A region crucial for the MOC is the northern North Atlantic and the adjacent Nordic Seas, where waters transported northward in the MOC upper limb progressively cool, gain density and eventually sink. Here we discuss the variability of the gyre circulation, the MOC and heat flux as quantified from a joint analysis of hydrographic and velocity data from six repeats of the Greenland to Portugal OVIDE section (1997-2010), satellite altimetry and Argo float measurements. For each repeat of the OVIDE section, the full-depth absolute circulation and transports were assessed using an inverse model constrained by ship-mounted Acoustic Doppler Current Profiler data and by an overall mass balance. The obtained circulation patterns revealed remarkable transport changes in the whole water column and evidenced large variations (up to $50 \%$ of the lowest value) in the magnitude of the MOC computed in density coordinates $\left(\mathrm{MOC}_{\sigma}\right)$. The extent and time scales of the $\mathrm{MOC}_{\sigma}$ variability in 1993-2010 were then evaluated using a monthly $\mathrm{MOC}_{\sigma}$ index built upon altimetry and Argo. The $\mathrm{MOC}_{\sigma}$ index, validated by the good agreement with the estimates from repeat hydrographic surveys, shows a large variability of the $\mathrm{MOC}_{\sigma}$ at OVIDE on monthly to decadal time scales. The intra-annual variability is dominated by the seasonal component with peak-to-peak amplitude of 4.3 Sv $\left(1 \mathrm{~Sv}=10^{6} \mathrm{~m}^{3} \mathrm{~s}^{-1}\right)$. On longer time scales, the $\mathrm{MOC}_{\sigma}$ index varies from less than $15 \mathrm{~Sv}$ to about $25 \mathrm{~Sv}$. It averages to $18.1 \pm 1.4 \mathrm{~Sv}$ and shows an overall decline of $2.5 \pm 1.4 \mathrm{~Sv}$ (95\% confidence interval) between 1993 and 2010. The heat flux estimates from repeat hydrographic surveys, which vary between 0.29 and $0.70 \pm 0.05$ $\mathrm{PW}$, indicate that the heat flux across the OVIDE section is linearly related to the MOC $\sigma$ intensity $(0.054 \mathrm{~Sv} / \mathrm{PW})$.
\end{abstract}

Regional terms: North Atlantic Ocean; Subpolar gyre; Irminger Sea; Iceland Basin; West European Basin; Iberian Abyssal Plain

\section{Highlights}

- We analyze the 1993-2010 variability of the $\mathrm{MOC}_{\sigma}$ at the Greenland-Portugal OVIDE line. We show that the $\mathrm{MOC}_{\sigma}$ can be monitored using Altimetry and Argo. The MOC $\sigma$ varies on monthly to decadal time scales. The $M \mathrm{CC}_{\sigma}$ shows an overall decline of $2.5 \pm 1.4 \mathrm{~Sv}$ between 1993 and 2010. The heat flux is linearly related to the $\mathrm{MOC}_{\sigma}$ magnitude.

Keywords : Meridional overturning circulation ; Thermohaline circulation ; Heat flux ; Argo ; Satellite altimetry ; Hydrography 


\section{Introduction}

Climate models suggest that the continuing increase in human emissions of carbon dioxide to the atmosphere will cause a slowdown of the Atlantic meridional overturning circulation (MOC) in the 21st century (Schmittner et al., 2005; Weaver et al., 2007; IPCC, 2007). The associated decline in the meridional oceanic heat flux will likely modify the heat loss from the ocean to the atmosphere in the North Atlantic region and affect the climate of the northern hemisphere (e.g., Vellinga and Wood, 2002; Latif et al., 2004; Semenov et al., 2010). The climate simulations also show that the Atlantic MOC is subject to energetic natural variability occurring on a variety of time scales (e.g., Schmittner et al., 2005), which masks the low-frequency signal and renders the detection of the predicted MOC decline challenging (Zhang et al., 2010).

Insights about the MOC decadal variability in the North Atlantic have been gained from model studies (e.g., Eden and Willebrand, 2001; Gulev et al., 2003; Marsh et al., 2005; Böning et al., 2006; Balmaseda et al., 2007; Zhang, 2010; Huang et al., 2012). Ocean models forced by atmospheric reanalysis (Marsh et al., 2005; Böning et al., 2006; Balmaseda et al., 2007; Huang et al., 2012; Desbruyères et al., 2012) have consistently suggested that the Atlantic MOC weakened by a few $\mathrm{Sv}\left(1 \mathrm{~Sv}=10^{6} \mathrm{~m}^{3} \mathrm{~s}^{-1}\right)$ since the mid-1990s in response to a weakening of the surface forcing associated with the decline in the North Atlantic Oscillation (NAO) index. The model studies have more broadly suggested a positive correlation on interannual to decadal time scales between the NAO, the MOC, the deep convection intensity in the Labrador Sea and the strength of the subpolar gyre cyclonic circulation (Eden and Willebrand, 2001; Gulev et al., 2003; Böning et al., 2006).

Because of the scarcity of historical transoceanic measurements and despite the recent progress in the development of observational networks, only a few observation-based estimates of the MOC variability in the North Atlantic are currently available. Based on the analysis of a set of hydrographic sections carried out in the North Atlantic in the late 1950s, early 1980s and early 1990s, Koltermann et al. (1999) have reported coherent decadal variability of the MOC at $48^{\circ} \mathrm{N}$ and $36^{\circ} \mathrm{N}$, as well as the lack of significant decadal signal at $24.5^{\circ} \mathrm{N}$. These authors suggested that in the 
$1950 \mathrm{~s}-1990 \mathrm{~s}$ the MOC at $48^{\circ} \mathrm{N}$ and $36^{\circ} \mathrm{N}$ was negatively correlated with the deep convection intensity in the Labrador Sea and positively correlated with the southward transport of the overflowderived deep waters. Focusing on the period from 1993 through 2000, Lumpkin et al. (2008) have found no significant trend in the MOC magnitude from the analysis of 5 repeats of the $48^{\circ} \mathrm{N}$ section. By combining satellite altimetry and Argo profiling float data, Willis (2010) has constructed a time series of the transport in the MOC upper limb at $41^{\circ} \mathrm{N}$. No trend in the MOC magnitude from 2002 through 2009 has been found, while altimetry data alone have suggested strengthening of the MOC by $2.6 \mathrm{~Sv}$ since 1993. A long-term slowdown of the MOC from 1957 through 2004 has been inferred by Bryden et al. (2005) from the analysis of 5 repeats of the $24.5^{\circ} \mathrm{N}$ section. This result has however been recently revisited based on data obtained from a transatlantic array of moored instruments deployed in the framework of the RAPID program, which has provided a continuous MOC time series at $26.5^{\circ} \mathrm{N}$ with daily resolution since 2004 (Cunningham et al., 2007). Using these data, Kanzow et al. (2010) have concluded that the aliasing due to the seasonal signal in the MOC magnitude possibly accounts for most of the trend reported by Bryden et al. (2005). Recently, based on data from a moored array located further to the south, at $16^{\circ} \mathrm{N}$, Send et al. (2011) have inferred a 〜3 Sv weakening of the MOC from January 2000 through June 2009.

In the northern North Atlantic, some variability of the MOC between August-September 1997, June-July 2002 and June-July 2004 has been reported by Lherminier et al. (2007; 2010) based on data from 3 repeats of the A25-OVIDE Greenland to Portugal section. The 2002-2008 mean summer (May-September) state of the MOC at $59.5^{\circ} \mathrm{N}$ has been assessed by Sarafanov et al. (2012) from repeat hydrographic measurements combined with satellite altimetry data. However, no information about the decadal variability of the MOC in the northern North Atlantic is available from observations.

In this study, we made an assessment of the variability of the MOC and heat flux across the A25-OVIDE Greenland to Portugal line in the northern North Atlantic (Figure 1) over 1993-2010 from 6 occupations of the line (1997-2010) in conjunction with satellite altimetry (1993-2010) and 
Argo float (2002-2010) data sets. As an additional source of hydrographic data extending back to 1993, we used the World Ocean Atlas (WOA) temperature and salinity fields. While earlier studies of the MOC variability in the extra-tropical North Atlantic have employed either repeat full-depth hydrography (e.g. Lumpkin et al., 2008; Lherminier et al., 2007; 2010) or a combination of satellite and float measurements (Willis, 2010), we took advantage here of all these three data sources. Based on CTD and absolute velocity data from the 6 repeats of the A25-OVIDE line, we obtained synoptic estimates of the large-scale circulation, the MOC magnitude and vertical structure, and the associated heat flux across the line at the time of the cruises. Then, we used these estimates as benchmarks for validating a monthly MOC index built upon a combination of altimetry and Argo float data. The results are discussed with a focus on the seasonal to decadal variability of the MOC since the early 1990s.

The manuscript is organized as follows. The data are described in Section 2. The large-scale circulation features, the MOC and their variability at A25-OVIDE, as estimated from repeat hydrographic measurements, are reported on in Section 3. The monthly time series of the MOC magnitude derived from Argo and altimetry data is presented and discussed in Section 4. Heat flux variability and its relation to the MOC variability are discussed in Section 5. We conclude the paper in Section 6.

\section{Data sets}

\subsection{OVIDE Greenland-Portugal section}

The primary data source was composed of (i) the five repeats of the Greenland-Portugal line occupied since 2002 every other year in the framework of OVIDE (Observatoire de la Variabilité Interannuelle à Décennale) project and (ii) the nearby A25-FOUREX line occupied in 1997 (Figure 1, Table 1). FOUREX measurements, referred to in the following as FOUREX 1997, have been described by Bacon (1998) and analyzed by Álvarez et al. (2002) and Lherminier et al. (2007). 
OVIDE 2002, 2004 and 2006 measurements have been presented and analyzed by Lherminier et al. (2007; 2010) and Gourcuff et al. (2011). New data collected along the OVIDE section in 2008 and 2010 complement our data set. Those six sections are referred to as the "OVIDE" sections hereafter.

About ninety hydrographic stations were occupied during each cruise. Prior to 2008, the CTD measurements were carried out using a Neil brown Mark III CTD probe, then a Sea-bird Electronics 911plus CTD probe was used. Overall, the CTD measurement accuracies are $1 \mathrm{dbar}$ for pressure, $0.002^{\circ} \mathrm{C}$ for temperature and 0.003 for salinity (see e.g. Billant et al., 2004 and Branellec et al., 2011). The station spacing was nominally of 25 nautical miles (NM) and was reduced to 16 NM in the Irminger Sea and 12 NM or less over steep topographic features.

Ship-mounted Acoustic Doppler Current Profiler (S-ADCP) measurements were combined with hydrography to estimate the absolute transports across the OVIDE line (see section 3.1). The SADCP measurements were obtained using a RD Instruments 150 kHz ADCP during FOUREX 1997 and a RD Instruments $75 \mathrm{kHz}$ ADCP during OVIDE. A high level of quality was achieved for the SADCP velocity data by correcting for the misalignment of the transducer orientation relative to the vessel axis and systematic bias in navigation heading. This was done by using the "bottom track" calibration procedure for FOUREX 1997 (Bacon, 1998) and by minimizing the correlation between the ship velocity and the current component along the ship trajectory during acceleration/deceleration phases for the OVIDE 2002 to OVIDE 2010 (Joyce, 1989; Lherminier et al., 2007; 2010). The estimated error on 1 minute averaged mean velocity is of the order of $0.03 \mathrm{~m} \mathrm{~s}^{-}$ 1. The velocity due to the barotropic tide was estimated and removed from the ADCP signal as explained by Lherminier et al. (2007).

For each survey, the Ekman transport orthogonal to the section was estimated from wind stress averaged over the months of the cruise. Depending on the availability of the wind stress products at the time of the cruise, different sources of wind stress were used: the European Centre Medium-Range Weather Forecast reanalysis ERA40 (Uppala et al., 2005) for FOUREX 1997 and OVIDE 2002, the CERSAT gridded products (available at http://cersat.ifremer.fr) for OVIDE 2004 
OVIDE 2006 and OVIDE 2008, and the monthly products of the NCEP/NCAR reanalysis for OVIDE 2010 (Kalnay et al. 1996). For the computation of the MOC time series presented in section 4, a homogeneous time series of the Ekman transport was derived from the NCEP/NCAR reanalysis wind stress data.

\subsection{Temperature and salinity gridded fields}

The monthly In Situ Analysis System (ISAS) provides gridded fields of temperature and salinity over the period 2002-2010 on a square horizontal grid of side equal to $0.5^{\circ} \mathrm{x} \cos$ (latitude), on 152 levels in the upper $2000 \mathrm{~m}$ (see http://wwz.ifremer.fr/lpo/SO-Argo/Products/Global-Ocean$\mathrm{T}-\mathrm{S})$. The vertical resolution is $5 \mathrm{~m}$ from the surface to $100 \mathrm{~m}$ depth, $10 \mathrm{~m}$ from $100 \mathrm{~m}$ to $800 \mathrm{~m}$ depth and $20 \mathrm{~m}$ from $800 \mathrm{~m}$ to $2000 \mathrm{~m}$ depth. The AN_V6-D7CA2S0 version of the ISAS fields was used to compute the sea-surface referenced monthly geostrophic velocities orthogonal to the OVIDE section. The ISAS fields were obtained by optimal interpolation of the large in situ data set provided by the Argo array of profiling floats and complemented by measurements from drifting buoys, CTDs and moorings (Gaillard et al., 2009; Gaillard, 2012). The data set was provided by the Coriolis data center, one of the Argo Global Data Acquisition Centers. In total, the Argo measurements account for at least $90 \%$ of the data employed by ISAS before and for more than $95 \%$ since 2006. The CTD data collected along the OVIDE line were excluded from the data base before performing the ISAS AN_V6-D2CA2S0 analysis, so that estimates derived from ISAS are fully independent from OVIDE data.

For the 1993-1996 time span, we used temperature and salinity fields constructed from objectively analyzed pentadal anomalies down to a depth of $2000 \mathrm{~m}$ and associated mean fields (Levitus et al., 2005; Boyer et al., 2005) available respectively at http://www.nodc.noaa.gov/OC5/ DATA_ANALYSIS/anomaly_data.html and http://www.nodc.noaa.gov/ OC5/ DATA_ANALYSIS/ sal_intro.html and released as part of the World Ocean Atlas 2005. These fields are referred to hereafter as the WOA data set. 


\subsection{AVISO mapped altimetry product}

Absolute sea-surface geostrophic velocities orthogonal to the OVIDE section were computed from the absolute dynamic topography, which is the sum of a sea level anomaly (SLA) and a mean dynamic topography (MDT). SLAs were from the multi-mission altimetry products provided by AVISO (gridded delayed time "upd" products) on a $1 / 3^{\circ}$ grid, with data every 7 days since October 1992 (http://www.aviso.oceanobs.com/en/data/products.html). We used the 2005 version of the MDT available on a ${ }^{1 / 2}{ }^{\circ}$ grid (Rio and Hernandez, 2004).

\section{Large scale circulation and MOC estimated from OVIDE hydrographic surveys}

\subsection{Method for the estimation of the circulation}

A linear box inverse model was used for the estimation of the absolute geostrophic field orthogonal to the OVIDE hydrographic section at the time of the cruise. The inverse model is based on the least squares formalism and follows the method of Jackson (1979), also described by Mercier (1986) and Lux et al. (2000). First, geostrophic velocities referenced to selected levels were computed for each pair of stations from CTD data. Then, the unknown velocities at the reference level were estimated by minimizing the weighted sum of (i) the squared departures from a priori values of the reference-level velocities, (ii) the squared residuals of transport constraints derived from the S-ADCP direct velocity measurements, and (iii) the squared residual of an overall mass conservation constraint. The weight of each constraint is inversely proportional to its uncertainty, such that constraints with large uncertainties bring less information than those with small uncertainties. The inverse model configurations have been described in detail by Lherminier et al. (2007) for FOUREX 1997 and OVIDE 2002, by Lherminier et al. (2010) for OVIDE 2004 and by Gourcuff et al. (2011) for OVIDE 2006. Our study builds on the circulation estimates reported by these authors as well as on new estimates obtained from OVIDE 2008 and OVIDE 2010 data. Model 
configurations used for the latter two cruises are not detailed here since they are similar to those previously reported for FOUREX 1997 and OVIDE 2002-OVIDE 2006. The least-squares formalism provides errors on the circulation and associated quantities such as the $\mathrm{MOC}_{\sigma}$ magnitude and the heat flux (see Lherminier et al., 2010).

The inverse model estimates of transports across OVIDE have been validated by favorable comparisons with independent measurements. The East Greenland-Irminger Current (EGIC, see Figure 1) transports from the inverse model for OVIDE 2004 and OVIDE 2006 have been shown to agree well with those obtained from concurrent and co-located moored current measurements (Daniault et al., 2011a). The EGIC transports from the inverse model for FOUREX 1997 and OVIDE 2002 are likewise consistent with transports obtained by combining the mooring data with altimetry (Daniault et al., 2011b). Gourcuff et al. (2011) have developed a method to estimate absolute transports across a hydrographic section by using altimetry instead of S-ADCP data to constrain the inverse model. They have applied the method to FOUREX 1997 and OVIDE 2002OVIDE 2006 and have reported on the North Atlantic Current (NAC), EGIC and heat transports. A good agreement has been shown between the results obtained with the S-ADCP data and those obtained with altimetry, although using altimetry resulted in errors $50 \%$ larger than when using SADCP data (Gourcuff et al., 2011).

\subsection{Large-scale circulation}

The main circulation features intersected by OVIDE (Figure 1) can be identified from the barotropic streamfunctions, which were computed for the six occupations of the section by accumulating the top-to-bottom integrated transports from Greenland to Portugal (Figure 2).

In the Irminger Sea, the barotropic streamfunction shows a well-documented cyclonic circulation (Figure 2, Fratantoni et al., 2001; Reverdin et al., 2003; Flatau et al., 2004, Lavender et al., 2000, Våge et al., 2011; Sarafanov et al., 2012). The southward limb is represented by the western boundary current observed above the Greenland continental slope (0-250 km in Figure 2). 
The northward limb of the cyclonic pattern (from $\sim 250 \mathrm{~km}$ to $\sim 700 \mathrm{~km}$ in Figure 2) is composed of two distinct branches associated, from west to east, with the eastern rim of the Irminger Gyre and with the Irminger Current (Figures 1 and 2; Våge et al., 2011; Sarafanov et al., 2012).

In the Iceland Basin, between the crest of the Reykjanes Ridge and the Eriador Seamount (Figures 1 and 2), the depth-integrated circulation is cyclonic (Figure 2, Sarafanov et al., 2012). Its northward limb is the western branch of the NAC. Surface drifters (Fratantoni et al., 2001), subsurface floats (Bower et al., 2002) and modeling studies (Treguier et al., 2005) have shown that the southwestward flow over the eastern side of the Reykjanes Ridge crosses the Ridge and joins the Irminger Current. A substantial flow of the NAC-derived waters across the Reykjanes Ridge, from the Iceland Basin to the Irminger Sea, has also been inferred from the volume balance north of the OVIDE section (Lherminier et al., 2010) and north of the $59.5^{\circ} \mathrm{N}$ section (Sarafanov et al., 2012). East of the Eriador Seamount, the barotropic streamfunction is dominated by the NAC, which is composed of a western and an eastern branch (Figures 1 and 2) with embedded energetic meanders and eddies. By an analysis of the upper ocean transports and hydrographic properties, Lherminier et al. (2010) have identified a westward shift of the western branch of the NAC between OVIDE 2002 and OVIDE 2004. This shift is apparent in the vertically integrated transports (Figure 2), which also show that at the time of OVIDE 2004-OVIDE 2010 the western branch of the NAC was located in the vicinity of the Eriador Seamount. The position of the NAC eastern branch is more variable. In the West European basin, the depth-integrated circulation is anticyclonic: the NAC feeds a southward flow in the vicinity of the Azores-Biscay Rise (Figures 1 and 2).

The barotropic streamfunction variability from one cruise to another is large. The western boundary current transport varied between 24 Sv (OVIDE 2006) and 43 Sv (OVIDE 2008) southward (Figure 2), which is within the range of variability expected from transports reported in the literature (see, e.g., Sarafanov et al., 2012, their Figure 10). The weak western bourndary current transport, as obtained from the OVIDE 2006 data, has been corroborated by Daniault et al. (2011a, b) and Gourcuff et al. (2011). The transport between the Reykjanes Ridge crest and the minimum in 
the barotropic streamfunction in the central Iceland Basin varied between 13 Sv (OVIDE 2002, OVIDE 2006) and $18 \mathrm{~Sv}$ (OVIDE 2008) southward. The depth-integrated northward transport computed between the minimum in the barotropic streamfunction in the Iceland Basin and the Portugal coast varied between 20 Sv (OVIDE 2010) and 48 Sv (OVIDE 2008). For comparison, Sarafanov et al. (2012) have found $23 \mathrm{~Sv}$ for the 2002-2008 mean depth-integrated northward transport in between the central part of the Iceland Basin and the European coast at $59.5^{\circ} \mathrm{N}$. The southward recirculation of the NAC in the West European basin across OVIDE was $\sim 10 \mathrm{~Sv}$ in agreement with the $\sim 8$ Sv reported by Paillet and Mercier (1997, their Figure 9).

\subsection{Meridional overturning circulation}

In order to quantify the thermohaline circulation that comprises the northward flow of warm and saline upper-ocean waters and the southward return flow of colder and fresher waters across the section (Marsh et al., 2005; Lherminier et al., 2007), we computed the meridional overturning streamfunction for each repeat of the OVIDE line, by integrating the Greenland to Portugal transports in density space, from the bottom to the sea surface (Figure 3). This streamfunction is designated as the $\mathrm{MOC}_{\sigma}$ (e.g., Lherminier et al., 2007); its maximum (referred to hereafter as the magnitude of the $\mathrm{MOC}_{\sigma}$, Table 2) corresponds to the net southward transport in the lower limb of the overturning cell.

The $\mathrm{MOC}_{\sigma}$ is a better measure of the thermohaline circulation at the latitudes of OVIDE than the MOC estimated in depth space $\left(\mathrm{MOC}_{\mathrm{z}}\right.$ ) (Marsh et al., 2005; Lherminier et al., 2007; Zhang, 2010). This is because the northward flow of warm waters transported by the NAC and the southward flow of colder and denser waters carried by the EGIC reside at overlapping depths so that they partially cancel each other out in the $\mathrm{MOC}_{\mathrm{z}}$. In density space, the NAC and EGIC are respectively ascribed to the warm (light) and cold (dense) limbs of the overturning cell (e.g., Lherminier et al., 2010). As a result, the magnitude of the $\mathrm{MOC}_{\sigma}$ is substantially larger than that of 
the $\mathrm{MOC}_{\mathrm{Z}}$ (Table 2) and unlike the latter the $\mathrm{MOC}_{\sigma}$ magnitude quantifies the light-to-dense water mass conversion north of the section (Grist et al., 2009).

The estimated $\mathrm{MOC}_{\sigma}$ magnitude at OVIDE varies between 11.4 Sv (OVIDE 2006) and 18.5 Sv (FOUREX 1997) (Table 2). The error on each value of the $\mathrm{MOC}_{\sigma}$ magnitude, based on the uncertainties of the lower limb velocities, is estimated at 2.4 Sv (Lherminier et al., 2010). The standard deviation is $2.5 \mathrm{~Sv}$. Since our cruises were carried out between May-June and AugustSeptember (Table 1), this variability is characteristic of summer, when, in models, the intra-annual variability of the $\mathrm{MOC}_{\sigma}$ at OVIDE is at a yearly minimum (Treguier et al., 2006). Models also suggest that because of the difference in the FOUREX 1997 and OVIDE 2002-OVIDE 2010 section paths (Figure 1), the $\mathrm{MOC}_{\sigma}$ magnitude at FOUREX 1997 might differ from that across the OVIDE section by $\sim 1 \mathrm{~Sv}$ on average (Treguier et al., 2006), which is smaller than the typical uncertainty in the $\mathrm{MOC}_{\sigma}$ estimates $( \pm 2.4 \mathrm{~Sv})$. The 1997-2010 mean MOC $\mathrm{M}_{\sigma}$ magnitude, as estimated from the 6 repeats of OVIDE, is $16.0 \pm 1 \mathrm{~Sv}$. The density at which the overturning streamfunction reaches a maximum $\left(\sigma_{\text {MOC }}\right)$ varied between $\sigma_{1}=32.1$ (OVIDE 2004) and $\sigma_{1}=32.2$ (OVIDE 2002) with a mean value of 32.14 (Figure 3, Table 2). There is no correlation between $\sigma_{\mathrm{MOC}}$ and the $\mathrm{MOC}_{\sigma}$ magnitude. This result can be understood in the light of Desbruyères et al. (2013, submitted) who have shown that the $\mathrm{MOC}_{\sigma}$ magnitude at OVIDE is correlated with the slope of $\sigma_{\mathrm{MOC}}$ east of the Reykjane Ridge rather than with its intrinsic value.

The magnitude of the $\mathrm{MOC}_{\sigma}$ upper limb is defined as the transport between $\sigma_{\mathrm{MOC}}$ and the sea surface. Its mean value is estimated at $17.0 \pm 1 \mathrm{~Sv}$, which is $1.0 \mathrm{~Sv}$ larger than the mean magnitude of the $\mathrm{MOC}_{\sigma}$ lower limb (Table 2). This difference comes from a northward transport of $1 \pm 3 \mathrm{~Sv}$ that was imposed in the inverse model as a constraint on the net transport across OVIDE in order to account for the flow of the upper-ocean waters that does not overturn north of OVIDE but recirculates in the surface layer through the Arctic Ocean and the Canadian Archipelago (see Lherminier et al., 2007). After inversion, the net transport across OVIDE and, hence, the difference 
between the magnitudes of the $\mathrm{MOC}_{\sigma}$ upper and lower limbs varied between $0.3 \mathrm{~Sv}$ southward (OVIDE 2004) and 2.2 Sv northward (FOUREX 1997) (Table 2).

\section{MOC variability estimated from altimetry and Argo}

In the previous section, variability of the $\mathrm{MOC}_{\sigma}$ at OVIDE was assessed from the 6 synoptic surveys. Hereafter, we quantify the $\mathrm{MOC}_{\sigma}$ variability at OVIDE from 1993 through 2010 by combining altimetry with ISAS or WOA temperature and salinity data sets. To do so, we estimated the net northward transport in the $\mathrm{MOC}_{\sigma}$ upper limb using an approach similar to that proposed by Willis (2010). The method is described in Section 4.1, the evaluation of the results is provided in Section 4.2 and the reconstructed $\mathrm{MOC}_{\sigma}$ time series is discussed in Section 4.3.

\subsection{Method for the estimation of the $M O C_{\sigma}$ variability from altimetry and Argo}

The monthly ISAS temperature and salinity gridded fields (available from January 2002 to December 2010 on 152 levels) were interpolated at $50 \mathrm{~km}$ spaced locations along the OVIDE section and the monthly dynamic heights referred to the sea surface were computed at each point of the horizontal/vertical grid. The weekly SLA and the MDT provided by AVISO were interpolated onto the horizontal grid. Then, the weekly absolute dynamic heights at the sea surface were computed as the sum of the MDT and SLA and were averaged to obtain monthly values. Next, the monthly in situ dynamic heights from ISAS were referenced to the monthly absolute dynamic heights at the sea surface and the absolute geostrophic velocity profiles orthogonal to the OVIDE section were calculated from the sea surface to $2000 \mathrm{~m}$. Finally, the geostrophic transports orthogonal to the section were computed from the gridded velocity field and the monthly Ekman transports orthogonal to the section $(\sim 1 \mathrm{~Sv}$ southward on average) were added to the shallowest level.

The monthly meridional overturning streamfunctions at OVIDE (Figure 4) were computed in density space using the total absolute transports across OVIDE (geostrophic plus Ekman) and ISAS- 
derived density fields. Maxima in the obtained streamfunctions define the monthly magnitudes of the $\mathrm{MOC}_{\sigma}$ upper limb (see Section 3.3). The time series of these magnitudes (Figure 5) is referred to in the following as the $\mathrm{MOC}_{\sigma}$ index. The associated uncertainty was estimated as the standard deviation of an ensemble of $100 \mathrm{MOC}_{\sigma}$ estimates obtained by random perturbations of both the ISAS temperature and salinity fields and the altimetry-derived surface dynamic heights, according to their respective error statistics. The standard errors for the ISAS fields were obtained from the objective analysis used for their estimation (Gaillard et al., 2009). These errors depend on the data distribution in time and space, the variance of the field and the noise in the data. The standard error for the surface dynamic height was chosen so as to result in an error of $0.03 \mathrm{~m} \mathrm{~s}^{-1}$ in surface velocity when calculated over a distance of $100 \mathrm{~km}$, as suggested by Gourcuff et al. (2011) from a comparison of AVISO altimetry products with S-ADCP data. We assumed that errors on the ISAS and altimetry fields were correlated over distances corresponding respectively to the correlation length used for constructing the ISAS fields $(250 \mathrm{~km})$ and the correlation distance for the AVISO data at OVIDE (100 km, Gourcuff et al., 2011).

In the absence of Argo measurements and, hence, ISAS fields before 2002, the $\mathrm{MOC}_{\sigma}$ index was extended back to 1993 (Figure 6) by combining altimetry data with the monthly mean density fields obtained by averaging the ISAS fields over 2002-2010. When using this approach (see also Willis, 2010), we assumed that most of the upper ocean transport changes at OVIDE are captured by the geostrophic surface velocities measured by the altimetry, at least on seasonal and longer time scales. To test the sensitivity of the $\mathrm{MOC}_{\sigma}$ index to the selected mean density field, we performed an additional estimate of the $\mathrm{MOC}_{\sigma}$ index for the 1993-1996 period by replacing the 2002-2010 mean ISAS fields with the pentadal WOA climatology (Figure 6). The mean difference between the two estimates is $0.4 \mathrm{~Sv}$, such that this substitution had a very minor impact on the results.

\subsection{Evaluation of the reconstructed fields}


The summer mean temperature and velocity fields estimated from ISAS and altimetry (Figures 7c and 7d) are qualitatively similar to the mean fields derived from the 5 hydrographic surveys OVIDE 2002-OVIDE 2010 (Figures 7a and 7b). The shape of the 32.14 isopycnal (the average $\sigma_{\mathrm{MOC}}$, see Section 3.3) is likewise correctly reproduced by ISAS (Figures 7a-7d). Closer inspection reveals that there is indeed no considerable bias between the two estimates east of $27^{\circ} \mathrm{W}$ (Figure 7e). Around $30^{\circ} \mathrm{W}$, however, the objective interpolation used for generating the ISAS fields smoothed the bowl associated with the anticyclonic circulation above the Reykjanes Ridge. This resulted in a local difference of 50-100 $\mathrm{m}$ in the mean depths of the 32.14 isopycnals between ISAS and repeat hydrography. The effect of this bias on the net transport in the $\mathrm{MOC}_{\sigma}$ upper limb is minor, as follows from the comparison of the mean transports accumulated from Greenland to Portugal within the $\mathrm{MOC}_{\sigma}$ upper limb (Figure 7f), which shows good agreement between the transports obtained from the ship-based data (referred to hereafter as "observed") and from altimetry and ISAS (referred to hereafter as "reconstructed"). No significant bias in the accumulated transports is found over the Reykjanes Ridge, nor at the Portugal end of the section, where the accumulated transport represents the magnitude of the $\mathrm{MOC}_{\sigma}$ upper limb.

Another indication of the reliability of the $\mathrm{MOC}_{\sigma}$ reconstruction comes from the comparison in Figure 8 of the observed and reconstructed overturning streamfunctions for August-September 1997 (FOUREX 1997) and June-July 2006 (OVIDE 2006), when the MOC $_{\sigma}$ magnitude was at its observed maximum and minimum, respectively (Table 2). The observed and reconstructed streamfunctions are qualitatively similar, and the difference in the magnitudes of the $\mathrm{MOC}_{\sigma}$ upper limb between the two synoptic estimates is $7-8 \mathrm{~Sv}$ for both estimates (Figure 8 ). As no monthly ISAS fields are available for 1997, the $\mathrm{MOC}_{\sigma}$ reconstruction for August-September 1997 relies on the monthly mean density fields from ISAS averaged over 2002-2010. This suggests that the MOC $\sigma$ index built for both the 2002-2010 and 1993-2010 time spans is able to reproduce the observed extreme synoptic states of the overturning circulation. The observed and reconstructed streamfunctions averaged over 2002-2010 (Figure 8) also show a remarkable similarity, and the 
mean $\sigma_{\mathrm{MOC}}$ in the reconstruction from altimetry and ISAS $\left(\sigma_{1}=32.14\right)$ matches the estimate based on the full-depth measurements at OVIDE (see Section 3.3). Finally, while being fully independent, the magnitudes of the observed and reconstructed $\mathrm{MOC}_{\sigma}$ agree within error bars (Figure 5).

To conclude, we find a good overall agreement between the reconstructed velocity fields from altimetry and ISAS and the ship-based observations in terms of meridional overturning streamfunction and $\mathrm{MOC}_{\sigma}$ magnitude. We will now focus on discussing the $\mathrm{MOC}_{\sigma}$ index.

\subsection{The $M O C_{\sigma}$ index}

The 2002-2010 mean magnitude of the reconstructed $\mathrm{MOC}_{\sigma}$ (Figure 5) is $18.1 \pm 1.4 \mathrm{~Sv}$. The error on the mean 2002-2010 $\mathrm{MOC}_{\sigma}$ was estimated as the standard deviation of the $\mathrm{MOC}_{\sigma}$ index over this time span divided by $\sqrt{N}$, where $N$ is number of independent estimates in the time series, to which we added $1 \mathrm{~Sv}$ to take into account errors in the MDT not accounted for by the method. Considering that no reliable estimate of the error in the MDT is available (see Gourcuff et al., 2011), this ad hoc procedure was implemented based on the differences $\sim 1 \mathrm{~Sv}$ found between MOC estimates based on the MDT used herein and those based on the MDT deduced from the OVIDE inversion-derived surface circulations.

The $\mathrm{MOC}_{\sigma}$ index averaged over summer months (May-September) from 2002 through 2008 $(16.9 \pm 1.5 \mathrm{~Sv}$ ) nearly matches the 2002-2008 mean summer (May-September) magnitude of the $\mathrm{MOC}_{\sigma}$ upper limb at $59.5^{\circ} \mathrm{N}(16.6 \pm 1.1 \mathrm{~Sv})$ reported by Sarafanov et al. (2012). The estimate by Sarafanov et al. (2012) and the $\mathrm{MOC}_{\sigma}$ index presented herein are not fully independent, as both estimates employ the MDT by Rio and Hernandez (2004) and altimetry data. Yet, the hydrographic data sets used in the two estimates are different: the ISAS fields in the present analysis and the fulldepth repeat hydrography at $59.5^{\circ} \mathrm{N}$ in the study by Sarafanov et al. (2012).

The 2002-2010 time series of the reconstructed $\mathrm{MOC}_{\sigma}$ suggests that the magnitude of the $\mathrm{MOC}_{\sigma}$ upper limb at OVIDE declined from $20.8 \pm 1.7 \mathrm{~Sv}$ in $2002-2003$ to $15.7 \pm 1.7 \mathrm{~Sv}$ in $2006-$ 
2007 and has recovered since then. Energetic higher-frequency variability is superimposed on this signal: on intra-seasonal time scales, the $\mathrm{MOC}_{\sigma}$ magnitude varied by more than $5 \mathrm{~Sv}$.

The $\mathrm{MOC}_{\sigma}$ index extended back to 1993 using altimetry and the ISAS temperature and salinity fields averaged over 2002-2010 is compared in Figure 6 with the MOC $\sigma$ index based on altimetry and the monthly ISAS fields (2002-2010), the $\mathrm{MOC}_{\sigma}$ index built upon altimetry and the pentadal WOA analysis (1993-1996) and the 6 synoptic estimates from repeat hydrographic measurements at OVIDE (FOUREX 1997, OVIDE 2002-OVIDE 2010). Despite a slight overestimation of the variability by altimetry alone, the comparison is quite favorable and altimetry alone clearly captures the main features of the variability. This is likely due to the fact that the $\mathrm{MOC}_{\sigma}$ upper limb at OVIDE represents a relatively thin upper layer (see Figure 7) in which the horizontal velocity anomalies are vertically correlated.

The 1993-2010 $\mathrm{MOC}_{\sigma}$ index exhibits apparent low-frequency variability at a timescale of 7-9 years: the index was higher than $20 \mathrm{~Sv}$ in 1993-1996, 2002-2003 and 2009-2010, and lower than 15 Sv in 1998-1999 and 2006-2007 (Figure 6). The steep decline in the MOC o $_{\sigma}$ index between 1996 and 2000 is consistent with the results from numerical modeling (e.g., Böning et al., 2006; Xu et al., 2013) that suggested a fast response of the MOC magnitude to the NAO-related weakening of the surface forcing. The 1993-2010 linear trend in the $\mathrm{MOC}_{\sigma}$ index estimated at $-2.5 \pm 1.4 \mathrm{~Sv}$ (95\% confidence level) suggests a significant decline of the $\mathrm{MOC}_{\sigma}$ at OVIDE since the early 1990s.

The intra-annual variability in the $\mathrm{MOC}_{\sigma}$ index shows a pronounced seasonal cycle (Figure 9) with maximum in winter, minimum in summer and peak-to-peak amplitude of $4.3 \mathrm{~Sv}$. This seasonality explains why the mean $\mathrm{MOC}_{\sigma}$ magnitude estimated from summer hydrographic measurements at OVIDE $\left(17.0 \pm 1 \mathrm{~Sv}\right.$ for the $\mathrm{MOC}_{\sigma}$ upper-limb) is smaller than the annual mean of the $\mathrm{MOC}_{\sigma}$ from the 2002-2010 reconstruction $(18.1 \pm 1.4 \mathrm{~Sv})$. The seasonal signal in the $\mathrm{MOC}_{\sigma}$ (Figure 9) is mostly due to the geostrophic $\mathrm{MOC}_{\sigma}$ seasonal signal, the seasonal Ekman signal being much weaker. Likewise, a study of the seasonal variability of the MOC at $26.5^{\circ} \mathrm{N}$ from the RAPID data set has revealed that the contributions of the variability of the Gulf Stream and interior 
geostrophic flow to the MOC seasonal variability were substantially larger than that of the Ekman component (Kanzow et al., 2010).

\section{Heat flux}

The heat flux (HF) across OVIDE was computed as $\iint \rho c_{p} \theta v d x d z$ where $\rho$ is in situ seawater density, $c_{p}$ is the specific heat capacity at constant pressure, $\theta=\theta(x, z)$ is potential temperature, $v(x, z)$ is the velocity orthogonal to the section, $x$ is the along section coordinate and $z$ is depth. HF estimated from the 6 occupations of the OVIDE line ranges between $0.70 \pm 0.5 \mathrm{PW}$ (FOUREX 1997) and 0.29 $\pm 0.5 \mathrm{PW}$ (OVIDE 2006) (Table 3), with a mean value of $0.51 \pm 0.06 \mathrm{PW}$ and a standard deviation of $0.14 \mathrm{PW}$. This mean HF value is within the HF range reported by Ganachaud and Wunsch (2003) for the $40^{\circ} \mathrm{N}-60^{\circ} \mathrm{N}$ latitude interval.

Classically, to get insight on the elements of circulation that influence HF variability, $v(x, z)$ and $\theta(x, z)$ are decomposed as $v(x, z)=v_{0}+\langle v\rangle(z)+v^{\prime}(x, z)$ and $\theta(x, z)=\langle\theta\rangle(z)+\theta^{\prime}(x, z)$ respectively, where $v_{0}$ is the section average velocity corresponding to the net transport across the section, $\langle v\rangle(z)$ and $\langle\theta\rangle(z)$ are horizontally averaged components and $v^{\prime}(x, z)$ and $\theta^{\prime}(x, z)$ are anomalies (Böning and Herrman, 1994; Álvarez et al., 2004). Denoting hereafter the area integration over the OVIDE section by an overbar ("), HF can then be written as:

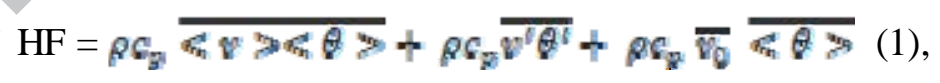

where the right hand side (r.h.s.) term is the sum, from left to right, of an overturning component $\left(\mathrm{HF}_{\mathrm{ov}}\right)$, a horizontal or gyre component $\left(\mathrm{HF}_{\mathrm{gyre}}\right)$ and a component associated with the net transport across the section $\left(\mathrm{HF}_{\text {net }}\right)$. To be consistent with the use of the $\mathrm{MOC}_{\sigma}$, the $\mathrm{HF}$ decomposition was performed herein in potential density $\left(\sigma_{1}\right)$ space rather than by using depth as vertical coordinate. Accordingly, the brackets in equation (1) now denote an average at constant density and the r.h.s. of equation (1) is the sum of a diapycnal component $\left(\mathrm{HF}_{\mathrm{dia}}\right)$, an isopycnal component $\left(\mathrm{HF}_{\mathrm{iso}}\right)$ and $\mathrm{HF}_{\text {net }}$ (Table 3). 
$\mathrm{HF}$ and its variability at OVIDE are largely explained by $\mathrm{HF}_{\text {dia }}$ (Table 3). Accordingly, $\mathrm{HF}_{\text {iso }}$ and $\mathrm{HF}_{\text {net }}$ are small, ranging between $-0.07 \mathrm{PW}$ and $0.08 \mathrm{PW}$ (Table 3). To indentify the mechanisms behind $\mathrm{HF}$ variability, $\mathrm{HF}_{\mathrm{dia}}$ was effectively approximated as $\rho c_{p} \Delta \theta \mathrm{MOC}_{\sigma}$ (see Table 3 ), where $\Delta \theta$ is the difference between the areal averages of the temperature over the upper and lower limbs of the $\mathrm{MOC}_{\sigma} . \rho$ and $c_{p}$ are constant and equal to $1027 \mathrm{~kg} \mathrm{~m}^{-3}$ and $3989 \mathrm{~J} \mathrm{~kg}^{-1} \mathrm{~K}^{-1}$, respectively. The mean of $\Delta \theta$ is $6.87^{\circ} \mathrm{C}$ and its standard deviation is $0.22^{\circ} \mathrm{C}$. If we impose the OVIDE hydrography-derived $1997-2010$ mean $\mathrm{MOC}_{\sigma}(17.0 \mathrm{~Sv}$ for the upper limb) as volume transport in the above approximation, a change in $\Delta \theta$ by one standard deviation $\left(0.22^{\circ} \mathrm{C}\right)$ would lead to a change of $0.014 \mathrm{PW}$ in $\mathrm{HF}$, which is an order of magnitude less than the standard deviation of $\mathrm{HF}_{\mathrm{dia}}(0.1 \mathrm{PW})$. The variability of $\mathrm{HF}_{\mathrm{dia}}$ at OVIDE is thus driven primarily by the variability of the $\mathrm{MOC}_{\sigma}$ and not by the temperature variability in the water column. In agreement with this inference, $\mathrm{HF}$ and $\mathrm{MOC}_{\sigma}$ are highly correlated $(r=0.93, \mathrm{p}<0.01)$, with a linear dependence of $0.054 \mathrm{PW} / \mathrm{Sv}$. As expected, the correlation between $\mathrm{HF}$ and $\mathrm{MOC}_{\mathrm{z}}$ is smaller and significant at a lower confidence level $(r=0.73, p=0.1)$. Accordingly, at high latitudes, the $\mathrm{MOC}_{\sigma}$ is a quantity better suited than the $\mathrm{MOC}_{\mathrm{z}}$ for assessment of HF variability.

\section{Summary and Discussion}

In this study, we analyzed six high-resolution repeats of the OVIDE Greenland-Portugal hydrographic section carried out in spring and summer between 1997 and 2010. For the first time from observations in the subpolar North Atlantic, we quantified the variability of the $\mathrm{MOC}_{\sigma}$, whose magnitude, defined as the net southward transport in the $\mathrm{MOC}_{\sigma}$ lower limb, varied between $11.4 \pm$ 2.4 Sv and 18.5 $\pm 2.4 \mathrm{~Sv}$ and had a mean value of $16.0 \pm 1 \mathrm{~Sv}$.

A 2002-2010 time series of the net northward transport in the $\mathrm{MOC}_{\sigma}$ upper limb (the $\mathrm{MOC}_{\sigma}$ index) at OVIDE was constructed with a monthly resolution by combining the sea-surface velocities derived from satellite altimetry with the Argo hydrographic data interpolated with ISAS. The method was validated by the close agreement between the $\mathrm{MOC}_{\sigma}$ index and the hydrographic 
estimates of the $\mathrm{MOC}_{\sigma}$ magnitude. The $\mathrm{MOC}_{\sigma}$ index was extended back to 1993 using altimetry data in combination with the ISAS monthly density fields averaged over 2002-2010 and the WOA data set for 1993-1996. At interannual to decadal scales, the $\mathrm{MOC}_{\sigma}$ variability (Figure 6) is barely sensitive to the choice of the hydrographic fields used in the analysis. That means that the changes in the velocity shears in the upper water column have a minor effect on the $\mathrm{MOC}_{\sigma}$ at OVIDE. The $\mathrm{MOC}_{\sigma}$ index averaged over $1993-2010$ and $2002-2010$ gives $18.7 \pm 1.3 \mathrm{~Sv}$ and $18.1 \pm 1.4 \mathrm{~Sv}$, respectively. Because of the distinct seasonal signal (the $\mathrm{MOC}_{\sigma}$ is stronger in winter, see Figure 9), these mean values are larger than the mean summer magnitude of the $\mathrm{MOC}_{\sigma}$ upper limb $(17.0 \pm 1 \mathrm{~Sv})$ derived from the OVIDE repeat hydrography. The summer (May-September) MOC $\sigma$ index averaged over 2002-2008 (16.9 $\pm 1.5 \mathrm{~Sv})$ practically matches the recent estimate of the 20022008 mean summer $\mathrm{MOC}_{\sigma}$ at $59.5^{\circ} \mathrm{N}(16.6 \pm 1.1 \mathrm{~Sv})$ (Sarafanov et al., 2012).

At $41^{\circ} \mathrm{N}$, Willis (2010) has reported a mean $\mathrm{MOC}_{\mathrm{z}}$ magnitude of $15.5 \pm 2.4 \mathrm{~Sv}$ for 2004 through 2006 in agreement with the 15.5 $\pm 1.8 \mathrm{~Sv}$ found for the $\mathrm{MOC}_{\sigma}$ index at OVIDE for the same period. This agreement is likely accidental because the vertical coordinates used in the two studies are different, and also because some contribution of the water mass transformation to the MOC magnitude is expected to occur in between $41^{\circ} \mathrm{N}$ and the Ovide line (e.g., Pickart and Spall, 2007). Furthermore, our estimate suggests a decrease in the $\mathrm{MOC}_{\sigma}$ strength of $2.5 \pm 1.4 \mathrm{~Sv}$ over 1993-2010 at OVIDE, which contrasts with the estimate by Willis (2010) who inferred a strengthening of $\mathrm{MOC}_{z}$ by $2.6 \mathrm{~Sv}$ since 1993 at $41^{\circ} \mathrm{N}$. Yet, our observation agrees with a similar decrease in MOC $\sigma$ magnitude found with the high-resolution Hybrid Coordinate Ocean Model at AR19 (about $46^{\circ} \mathrm{N}$ ) on the same time period (Xu et al., 2013, their Figure 13b). According to those authors, the drop in MOC $_{\sigma}$ observed between 1996 and 2000 (that is mainly responsible for the trend found in this study) would be part of a decadal variability, and their simulation shows no significant trend for 19782011.

From the analysis of the decadal variability in the $14^{\circ}$ ocean general circulation model simulation ORCA025-G70, Desbruyères et al. (2013) have shown a decrease in the $\mathrm{MOC}_{\sigma}$ 
magnitude at OVIDE between the mid-1990's and 2004. Using a Lagrangian method, they also identified two vertical overturning cells contributing to the $\mathrm{MOC}_{\sigma}$ at OVIDE: a "subtropical cell" connecting low and high latitudes (12 Sv) and a cell internal to the subpolar gyre (4 Sv). The significance of this result is that the comparison of the mean magnitude of the MOC $\sigma$ at OVIDE and at lower latitudes is not straightforward.

The $\mathrm{MOC}_{\sigma}$ index exhibits variability from monthly to decadal time scales. On intra-seasonal time scales, the $\mathrm{MOC}_{\sigma}$ magnitude variations exceed $5 \mathrm{~Sv}$. The peak-to-peak amplitude of the seasonal cycle of the $\mathrm{MOC}_{\sigma}$ is of about $4 \mathrm{~Sv}$, which agrees with the results from an analysis of the $1 / 6^{\circ}$ simulation of the Clipper ocean model (Treguier et al., 2006). A lower-frequency variability of the $\mathrm{MOC}_{\sigma}$ at OVIDE in 1993-2010 exhibits a signal at a time scale of 7 to 9 years and an overall decline since 1993. Remarkably, the drop in the $\mathrm{MOC}_{\sigma}$ magnitude after the change in the NAO from a positive phase to a negative phase in 1996 is found in most numerical models (Marsh et al., 2005; Treguier et al., 2006; Huck et al., 2008; Desbruyères et al., 2013). Analyzing the decadal variability in the ORCA025-G70 simulation, Desbruyères et al. (2013) have shown that the 10-year low-passed filtered simulated $\mathrm{MOC}_{\sigma}$ variability at OVIDE is correlated with the NAO $(\mathrm{r}=0.7$, significant at the $95 \%$ confidence level), the NAO leading the $\mathrm{MOC}_{\sigma}$ by 4 to 5 years. Here we find that the winter NAO leads the annual average $\mathrm{MOC}_{\sigma}$ index by 2 years $(\mathrm{r}=0.45, \mathrm{p}=0.03)$, which is in line with previous results that have indicated that the circulation in the eastern subpolar gyre responds to the NAO with a 2 year lag (Bersch, 2002).

Hydrographic estimates of HF across OVIDE ranges between $0.29 \pm 0.05 \mathrm{PW}$ and $0.70 \pm 0.05 \mathrm{PW}$. HF is much closely correlated with the $\mathrm{MOC}_{\sigma}(\mathrm{r}=0.93)$ than with the $\mathrm{MOC}_{\mathrm{z}}$ $(r=0.73)$, and, hence, in the northern North Atlantic, variability of the MOC estimated into density space is a better proxy for oceanic heat transport variability. By decomposing the HF in a diapycnal component $\left(\mathrm{HF}_{\mathrm{dia}}\right)$ and an isopycnal component $\left(\mathrm{HF}_{\mathrm{iso}}\right)$, we showed that $\mathrm{HF}_{\mathrm{dia}}$, associated with the water mass conversion, explains $87 \%$ of the heat flux. By contrast, Álvarez et al. (2002) have 
reported an equal partition of $\mathrm{HF}$ between $\mathrm{HF}_{\text {gyre }}$ and $\mathrm{HF}_{\mathrm{ov}}$, by decomposing the heat flux across FOUREX 1997 in $z$ coordinates. The mean value of HF at OVIDE, $0.5 \pm 0.06 \mathrm{PW}$, is in general agreement with the regional estimates of HF based on hydrographic data (Koltermann et al., 1999; Ganachaud and Wunsch, 2003) and atmospheric reanalysis (Trenberth and Caron, 2001).

The inferred $\sim 2.5 \mathrm{~Sv}$ decrease in the magnitude of the $\mathrm{MOC}_{\sigma}$ upper limb at OVIDE since 1993 should be balanced by a similar decrease in the net southward transport in the MOC lower limb. An essential element of the MOC lower limb at OVIDE being the Deep Western Boundary Current (DWBC, see Figure 1), one might therefore expect that a decline in the $\mathrm{MOC}_{\sigma}$ is accompanied by a decrease in the DWBC transport. Recent observation-based studies (Sarafanov et al., 2009; Sarafanov et al., 2010; Våge et al., 2011) have shown, however, an increase in the DWBC transport between the early 1990s and the late 2000s by about $2 \mathrm{~Sv}$ at the location of OVIDE. The estimate by Våge et al. (2011) suggests an increase in the DWBC transport at a rate of $1.5 \mathrm{~Sv} / 10$ years from 1991 through 2007. Over the same time span, the net top-to-bottom transport of the Western Boundary Current (WBC) decreased by about 2 Sv due to a weakening of the circulation above the DWBC (Våge et al., 2011), which agrees with the decline of the large scale cyclonic circulation in the subpolar gyre of the North Atlantic since the mid-1990's (Hakkinen and Rhines, 2004, 2009). Accordingly, these results suggest that the decrease in the northward transport in the $\mathrm{MOC}_{\sigma}$ upper limb at OVIDE in the 1990s-2000s was balanced, at least partially, by a decrease in the southward export of intermediate waters in the western Irminger Sea within the $\mathrm{MOC}_{\sigma}$ lower limb. The spatial pattern of temporal changes in the MOC lower limb in the 1990s-2000s needs further investigation though, which is beyond the scope of the present study.

A general conclusion from the analysis performed herein is that a monitoring of the MOC in the northern North Atlantic is possible from sustained measurements. The method we presented can be applied for estimation of the $\mathrm{MOC}_{\sigma}$ variability at sections, such as OVIDE, where the MOC $\sigma$ upper limb represents a broad northward flow not interacting with bathymetry. In this case, the 
variability of the upper-ocean northward transport can be efficiently resolved by satellite altimetry and Argo float measurements. The method might not be applicable at latitudes where the northward transport in the $\mathrm{MOC}_{\sigma}$ upper limb is concentrated at the western boundary.

\section{Acknowledgments}

We thank all who contributed to the hydrographic and satellite data acquisition and processing. H. Mercier and C. Gourcuff were supported by the French National Center for Scientific Research (CNRS), P. Lherminier and F. Gaillard by the French Institute for Marine Science (Ifremer) and N. Daniault by the European University of Brittany. A. Sarafanov and A. Falina were supported by the Russian Ministry of Education and Science under the "World Ocean" Federal Programme (contract 01.420.1.2.0001), the RFBR grants 11-05-00555 and 12-05-91056-CNRS, and the Russian President grant MK-5357.2012.5. The OVIDE project was supported by CNRS, Ifremer, the national program LEFE (Les Enveloppes Fluides et l'Environnement) and PICS (Projet International de Coopération Scientifique) $n^{\circ} 6058$. 


\section{References}

Álvarez, M.F., Bryden, H.L., Pérez, F.F., Ríos, A.F., Roson, G., 2002. Physical and biogeochemical fluxes and net budgets in the subpolar and temperate North Atlantic. J. Marine Res. 60 (2), 191226.

Álvarez, M.F., Pérez, F.F., Bryden, H.L., Ríos, A.F., 2004. Physical and biochemical transports structure in the North Atlantic subpolar gyre. J. Geophys. Res. 109, C03027, doi:10.1029/2003JC002015.

Bacon, S., 1998. RRS Discovery Cruise 230, 07 Aug-17 Sep 1997. Two hydrographic sections across the boundaries of the subpolar gyre: FOUREX. Southampton Oceanography Centre, Southampton, UK, 104pp. http://eprints.socon.ac.uk/306/.

Balmaseda, M.A., Smith, G.C., Haines, K., Anderson, D., Palmer, T.N., Vidard, A., 2007. Historical reconstruction of the Atlantic meridional overturning circulation from the ECMWF operational ocean reanalysis. Geophys. Res. Lett. 34 (23), L23615, doi:10.1029/2007GL031645.

Bersch, M., 2002. North Atlantic Oscillation-induced changes in the upper layer circulation in the northern North Atlantic. J. Geophys. Res., 107(C10), 223-235, doi :10.1029/2001JC000901.

Billant, A., Branellec, P., Mercier, H., 2004. Campagne OVIDE 2002 : Rapport de données CTDO2, Tech. Rep. DRO/DOPS/04-01.

Böning, C.W., Herrmann, P., 1994. Annual cycle of poleward heat transport in the ocean: results from high-resolution modeling of the north and equatorial Atlantic. J. Phys. Oceanogr. 24, 91107.

Böning, C.W., Scheinert, M., Dengg, J., Biastoch, A., Funk, A., 2006. Decadal variability of subpolar gyre transport and its reverberation in the North Atlantic overturning. Geophys. Res. Lett., 33, L21S01, doi:10.1029/2006GL026906. 
Bower, A.S., Le Cann, B., Rossby, T., Zenk, W., Gould, J., Speer, K.G., Richardson, P.L., Prater, M.D., Zhang, H.-M., 2002. Directly measured mid-depth circulation in the northeastern North Atlantic Ocean. Nature, 419, 603-607.

Boyer, T.P., Levitus, S., Antonov, J.I., Locarnini, R.A., Garcia, H.E., 2005. Linear trends in salinity for the World Ocean, 1955-1998. Geophys. Res. Lett. 32 (1), L01604, doi:10.1029/2004GL021791.

Branellec, P., Ferron, B., Lherminier, P., 2011. Campagne OVIDE 2008: Rapport de données CTDO2, Tech. Rep. ODE/OPS/LPO/11-03.

Bryden, H.L., Longworth, H.R., Cunningham, S.A., 2005. Slowing of the Atlantic meridional overturning circulation at 25 degrees N. Nature, 438, 655-657, doi:10.1038/nature04385.

Cunningham, S.A., Kanzow, T., Rayner, D., Baringer, M.O., Johns, W.E., Marotzke, J., Longworth, H.R., Grant, E.M., Hirschi, J.J., Beal, L.M., Meinen, C.S., Bryden, H.L., 2008. Temporal variability of the Atlantic meridional overturning circulation at 26.5N. Science, 317, 935-937.

Daniault, N., Lherminier, P., Mercier, H., 2011a. Circulation and transport at the southeast tip of Greenland. J. Phys. Oceanogr. 41 (3), 437-457, doi:10.1175/2010JPO4428.1.

Daniault, N., Mercier, H., Lherminier, P., 2011b. The 1992-2009 transport variability of the East Greenland-Irminger Current at 60N. Geophys. Res. Lett. 38, L07601, doi:10.1029/2011GL046863.

Desbruyères, D., Thierry, V., Mercier, H., 2013. Simulated decadal variability of the Meridional Overturning Circulation across the A25-Ovide section. J. Geophys. Res. Oceans 118, 462-475, doi:10.1029/2012JC008342, in press.

Desbruyères, D., Mercier, H., Thierry, V., 2013. On the mechanisms behind the decadal heat content changes in the eastern subpolar gyre. Progress Oceanogr., submitted to this special issue.

Eden, C., Willebrand, J., 2001. Mechanism of interannual to decadal variability of the North Atlantic circulation. J. Climate 14, 2266-2280. 
Flatau, M.K., Talley, L.D., Niiler, P.P., 2003. The North Atlantic Oscillation, surface current velocities, and SST changes in the Subpolar North Atlantic. J. Climate 16, 2355-2369.

Fratantoni, P. S., 2001. North Atlantic surface circulation during the 1990's observed with satellitetracked drifters. J. Geophys. Res. 106 (C6), 22067-22093.

Gaillard, F., 2012. ISAS-Tool Version 6: Method and configuration. http://archimer.ifremer.fr/doc/00115/22583.

Gaillard, F., Autret, E., Thierry, V., Galaup, P., Coatanoan, C., Loubrieu, T., 2009. Quality control of large Argo datasets. J. Atmos. Oceanic Technol. 26 (2), 337-351, doi:10.1175/2008JTECHO552.1.

Ganachaud, A., Wunsch, C., 2003. Large-scale ocean heat and freshwater transports during the World Ocean Circulation Experiment. J. Climate 16, 696-705.

Gourcuff, C., Lherminier, P., Mercier, H., Le Traon, P.Y., 2011. Altimetry combined with hydrography for ocean transport estimation. J. Atmos. Oceanic Technol. 28 (10), 1324-1337, doi:10.1175/2011JTECHO818.1.

Grist, J.P., Marsh, R., Josey, S.A., 2009. On the relationship between the North Atlantic meridional overturning circulation and the surface-forced overturning streamfunction. J. Climate 22 (19), 4989-5002, doi:10.1175/2009JCLI2574.1.

Gulev, S.K., Barnier, B., Knochel, H., Molines, J.M., Cottet, M., 2003. Water mass transformation in the North Atlantic and its impact on the meridional circulation: Insights from an ocean model forced by NCEP-NCAR reanalysis surface fluxes. J. Climate 16 (19), 3085-3110, doi:10.1175/1520-0442(2003)016<3085:WMTITN>2.0.CO;2.

Hakkinen, S., Rhines, P.B., 2004. Decline of Subpolar North Atlantic Circulation During the 1990s. Science 304 (5670), 555-559, DOI: 10.1126/science.1094917.

Hakkinen, S., Rhines, P.B., 2009. Shifting surface currents in the northern North Atlantic Ocean. J. Geophys. Res. 114, C04005, doi:10.1029/2008JC004883. 
Huang, B., Xue, Y., Kumar, A., Behringer, D.W., 2012. AMOC variations in 1979-2008 simulated by NCEP operational ocean data assimilation system. Climate Dynamics 38 (3-4), 513-525, doi:10.1007/s00382-011-1035-z.

Huck, T., Colin de Verdière, A.C., Estrade, P., Schopp, R., 2008. Low-frequency variations of the large-scale ocean circulation and heat transport in the North Atlantic from 1955-1998 in situ temperature and salinity data. Geophys. Res. Lett. 35, L23613, doi:10.1029/2008GL035635.

IPCC - Intergovernmental Panel on Climate Change, 2007. Climate Change 2007: The Physical Science Basis. Contribution of Working Group I to the Fourth Assessment Report of Intergovernmental Panel on Climate Change. Solomon, S., Qin, D., Manning, M., Chen, Z., Marquis, M., Averyt, K.B., Tignorand, M., Miller, H.L. (eds.), Cambridge University Press, Cambridge, United Kingdom and New-York, NY, USA.

Jackson, D.D., 1979. Use of a priori data to resolve non-uniqueness in linear inversion. Geophys. J. R. Astron. Soc. 57 (1), 137-157, doi:10.1111/j.1365-246X.1979.tb03777.x.

Joyce, T. M., 1989. On in situ calibration of shipboard ADCP. J. Atmos. Oceanic Technol. 6 (2), 169-172.

Kalnay, E., Kanamitsu, M., Kistler, R., et al.,1996. The NCEP/NCAR 40-year reanalysis project. Bull. Amer. Meteor. Soc. 77, 437-470.

Kanzow, T., Cunningham, S.A., Johns, W.E., Hirschi, J.J.-M., Marotzke, J., Baringer, M.O., Meinen, C.S., Chidichimo, M.P., Atkinson, C., Beal, L.M., Bryden, H.L., Collins, J., 2010. Seasonal variability of the Atlantic meridional overturning circulation at $26.5^{\circ} \mathrm{N}$. J. Climate 23 , 5678-5698, DOI:10.1175/2010JCLI3389.1.

Koltermann, K.P., Sokov, A., Tereschenkov, V.P., Dobroliubov, S.A., Lorbacher, K., Sy, A., 1999. Decadal changes in the thermohaline circulation of the North Atlantic. Deep-Sea Res. II 46, 109-138. 
Latif, M., Böning, C.W., Willebrandt, J., Biastoch, A., Alvarez-Garcia, F., Keenlyside, N., Pohlmann, H., 2007. Decadal to multidecadal variability of the Atlantic MOC: mechanisms and predictability. In : Schmittner, A., Chiang, J.C.H., Hemming, S.R. (Eds), Ocean circulation: mechanisms and impacts-Past and future changes of meridional overturning. Geophysical Monograph Series 173, American Geophysical Union, Washington, N.W., pp. 149-166.

Lavender, K.L., Owens, W.B., Davis, R.E., 2005. The mid-depth circulation of the subpolar North Atlantic Ocean as measured by subsurface floats. Deep-Sea Res. I 52, 767-785.

Levitus, S., Antonov, J., Boyer, T., 2005. Warming of the world ocean, 1955-2003. Geophys. Res. Lett. 32 (2), L02604, doi:10.1029/2004GL021592.

Lherminier, P., Mercier, H., Gourcuff, C., Álvarez, M.F., Bacon, S., Kermabon, C., 2007. Transport across the 2002 Greenland-Portugal section and comparison with 1997. J. Geophys. Res. 112, C07003, doi:10.1029/2006JC003716.

Lherminier, P., Mercier, H., Huck, T., Gourcuff, C., Perez, F.F., Morin, P., Sarafanov, A., Falina, A., 2010. The Atlantic Meridional Overturning Circulation and the subpolar gyre observed at the A25-OVIDE section in June 2002 and 2004. Deep-Sea Res. I 57 (11), 1374-1391, doi:10.1016/j.dsr.2010.07.009.

Lumpkin, R., Speer, K.G., Koltermann, K.P., 2008. Transports across $48^{\circ} \mathrm{N}$ in the Atlantic Ocean. J. Phys. Oceanogr. 38, 733-752, doi:10.1175/2007JPO3636.1.

Lux, M., Mercier, H., Arhan, M., 2000. Interhemispheric exchanges of mass and heat in the Atlantic Ocean in January-March 1993. Deep-Sea Res. I 48, 605-638.

Marsh, R., de Cuevas, B.A., Coward, A.C., Bryden, H.L., Álvarez, M.F., 2005. Thermohaline circulation at three key sections in the North Atlantic over 1985-2002. Geophys. Res. Lett., 32, L10604, doi:10.1029/2004GL022281.

Mercier, H., 1986. Determining the general circulation of the ocean - A nonlinear inverse problem. J. Geophys. Res. 91 (C4), 5103-5109, doi:10.1029/JC091iC04p05103. 
Paillet, J., Mercier, H., 1997. An inverse model of the eastern North Atlantic general circulation and thermocline ventilation. Deep-Sea Res. I 44, 1293-1328.

Pickart, R. S., Spall, M. A., 2007. Impact of Labrador Sea convection on the North Atlantic Meridional Overturning Circulation. J. Phys. Oceanogr. 37, 2207-2227, doi:10.1175/ JPO3178.1.

Reverdin, G., Niiler, P.P., Valdimarsson, H., 2003. North Atlantic Ocean surface currents. J. Geophys. Res. 108 (C1), 1-23, doi:10.1029/2001JC001020.

Rio, M.-H., Hernandez, F., 2004. A mean dynamic topography computed over the world ocean from altimetry, in situ measurements, and a geoid model. J. Geophys. Res. 109, C12032, doi:10.1029/2003JC002226.

Sarafanov, A., Falina, Mercier, H., Lherminier, P., Sokov, A., 2009. Recent changes in the Greenland-Scotland oberflow-derived water transport inferred from hydrographic observations in the southern Irminger Sea. Geophys. Res. Lett. 36, L13606, doi:10.1029/2009GL038385.

Sarafanov, A., Falina, A., Lherminier, P., Mercier, H., Sokov, A., Gourcuff, C., 2010. Assessing decadal changes in the Deep Western Boundary Current absolute transport southeast of Cape Farewell, Greenland, from hydrography and altimetry. J. Geophys. Res. 115, C11003, doi:10.1029/2009JC005811.

Sarafanov, A., Falina, A., Mercier, H., Sokov, A., Lherminier, P., Gourcuff, C., Gladyshev, S., Gaillard, F., Daniault, N., 2012. Mean full-depth summer circulation and transports at the northern periphery of the Atlantic Ocean in the 2000s. J. Geophys. Res. 117, C01014, doi:10.1029/2011JC007572.

Schmittner, A., Latif, M., Schneider, B., 2005. Model projections of the North Atlantic thermohaline circulation for the 21 st century assessed by observations. Geophys. Res. Lett. 32 (23), L23710, doi:10.1029/2005GL024368. 
Semenov, V.A., Latif, M., Dommenget, D., Keenlyside, N.S., Strehz, A., Martin, T., Park, W., 2010. The impact of North Atlantic-Arctic multidecadal variability on northern hemisphere surface air temperature. J. Climate 23 (21), 5668-5677, doi:10.1175/2010JCLI3347.1.

Send, U., Lankhorst, M., Kanzow, T., 2011. Observation of decadal change in the Atlantic meridional overturning circulation using 10 years of continuous transport data. Geophys. Res. Lett. 38, L24606, doi:10.1029/2011GL049801.

Treguier, A.-M., Theetten, S., Chassignet, E.P., Penduff, T., Smith, R., Talley, L.D., Beismann, J.O., Böning, C.W., 2005. The North Atlantic subpolar gyre in four high-resolution models. J. Phys. Oceanogr. 35 (5), 757-774, doi:10.1175/JPO2720.1.

Treguier, A.-M., Gourcuff, C., Lherminier, P., Mercier, H., Barnier, B., Madec, G., Molines, J.-M., Penduff, T., Czeschel, L., Böning, C.W., 2006. Internal and forced variability along a section between Greenland and Portugal in the CLIPPER Atlantic model. Oceans Dyn. 56, 568-580.

Trenberth, K.E., Caron, J.M., 2001. Estimates of meridional atmosphere and ocean heat transports. J. Climate 14 (16), 3433-3443, doi:10.1175/1520-0442(2001)014<3433:EOMAAO>2.0.CO;2.

Uppala, S.M., and 46 co-authors, 2005. The ERA-40 re-analysis. Quart. J. Roy. Meteor. Soc. 131, 2961-3012.

Våge, K., Pickart, R.S., Sarafanov, A., Knutsen, O., Mercier, H., Lherminier, P., Van Aken, H.M., Meincke, J., Quadfasel, D., 2011. The Irminger Gyre: circulation, convection and interannual variability. Deep-Sea Res. I 58, doi:10.1016/j.dsr.2011.03.001.

Vellinga, M., Wood, R.A., Gregory, J.M., 2002. Processes governing the recovery of a perturbed thermohaline circulation in HadCM3. J. Climate 15 (7), 764-780, doi:10.1175/15200442(2002)015<0764:PGTROA>2.0.CO;2.

Weaver, A.J., Eby, M., Kienast, M., Saenko, O.A., 2007. Response of the Atlantic meridional overturning circulation to increasing atmospheric $\mathrm{CO}_{2}$ : Sensitivity to mean climate state. Geophys. Res. Lett. 34 (5), L05708, doi:10.1029/2006GL028756. 
Willis, J.K., 2010. Can in situ floats and satellite altimeters detect long-term changes in Atlantic Ocean overturning? Geophys. Res. Lett. 37, L06602, doi:10.1029/2010GL042372.

Xu, X., Hulburt, H.E., Schmitz Jr., W.J., Zantopp, R., Fischer, J., Hogan, J., 2013. On the currents and transports connected with the Atlantic Meridional Overturning Circulation in the subpolar North Atlantic. J. Geophys. Res., in press, doi: 10.1002/jgrc.20065.

Zhang, R., 2010. Latitudinal dependence of Atlantic meridional overturning circulation (AMOC) variations. Geophys. Res. Lett. 37, L16703, doi:10.1029/2010GL044474.

Zhang, S., Rosati, A., Delworth, T., 2010. The adequacy of observing systems in monitoring the Atlantic meridional overturning circulation and North Atlantic climate. J. Climate 23 (19), 5311-5324, doi:10.1175/2010JCLI3677.1. 


\section{Figure captions}

Figure 1: Schematic circulation in the North Atlantic in between the A25-OVIDE line and the Greenland-Scotland Ridge. The main pathways of waters originating from the Atlantic Ocean and the Nordic seas are shown, respectively, with the pink and blue lines. The locations of the OVIDE and A25 (FOUREX) hydrographic sections are indicated. Bathymetry is shown with the blue shading. Abbreviations for the main currents and topographic features are as follows: DWBC = Deep Western Boundary Current, EGC = East Greenland Current, EGIC = East Greenland Irminger Current, IC = Irminger Current, IG = Irminger gyre, NAC = North Atlantic Current, NIIC = North Icelandic Irminger Current, WNAC and ENAC = western and eastern branches of the NAC, respectively, $\mathrm{ABR}=$ Azores-Biscay Ridge, $\mathrm{BFZ}=$ Bight Fracture Zone, $\mathrm{CGFZ}=$ Charlie Gibbs Fracture Zone, ESM = Eriador Seamount, FSC = Faroe-Scotland Channel, IAP = Iberian Abyssal Plain, $R R=$ Reykjanes Ridge, $R B=$ Rockall Bank. Compiled from Lherminier et al. (2010) and Sarafanov et al. (2012).

Figure 2: Upper panel - Cumulative sum of the depth-integrated transports ( $\mathrm{Sv}$ ) from Greenland to Portugal, for the 6 occupations of the OVIDE section. The dash grey line and the grey shading represent the mean and the standard deviation of the OVIDE 2002 - OVIDE 2010 barotropic streamfunctions. The main currents are indicated. The bathymetry along the OVIDE line is displayed in the lower panel.

Figure 3: Meridional overturning streamfunctions (Sv) obtained for the 6 occupations of the OVIDE section by integrating the Greenland to Portugal horizontal transports in 0.01 density bins from the bottom with potential density anomaly referenced to $1000 \mathrm{db}\left(\sigma_{1}\right.$ in $\left.\mathrm{kg} \mathrm{m}^{-3}\right)$ as vertical coordinate. Sign has been changed for convenience of comparison with Figures 4 and 8 . The maximum in the streamfunction defines the magnitude of the $\mathrm{MOC}_{\sigma}$ lower limb. The horizontal line represents the mean value of $\sigma_{\mathrm{MOC}}$. 
Figure 4: Monthly meridional overturning streamfunctions at OVIDE (Sv) for 2002-2010 as computed from altimetry and ISAS with $\sigma_{1}\left(\mathrm{~kg} \mathrm{~m}^{-3}\right)$ as vertical coordinate. The integration of the Greenland-to-Portugal transports was performed in 0.025 density bins from the sea surface (for convenience, the streamfunction is displayed for $\sigma_{1}>31$ only). The red circles mark the magnitude of the $\mathrm{MOC}_{\sigma}$ upper limb.

Figure 5: Time series of the monthly $\mathrm{MOC}_{\sigma}$ upper limb transport (Sv) for 2002-2010 computed from AVISO and ISAS data sets as explained in Section 4.1. The error bar is in grey. MOC $\sigma$ estimates from Ovide inversions and the associated errors are in red.

Figure 6: Time series of the monthly $\mathrm{MOC}_{\sigma}$ upper limb transport (Sv) for 1993-2010 obtained from AVISO, ISAS and WOA data sets as explained in Section 4.1. The blue curve is the MOC $\sigma$ computed from AVISO combined with the monthly mean velocity fields derived from ISAS and averaged over the 2002-2010 time span. The grey envelope indicates the uncertainty that was defined as the maximum error in the estimate for 2002-2010 (2.6 Sv). The green curve is the lowpass filtered time series using a 2-year running mean. The black curves are the $\mathrm{MOC}_{\sigma}$ computed from AVISO and WOA pentadal analysis (1993-1996) and from AVISO and ISAS data sets (20022010, see Figure 5). The $\mathrm{MOC}_{\sigma}$ estimates from OVIDE inversions and the associated errors are in red.

Figure 7: The 2002-2010 mean temperature (a) and velocity (b) fields as a function of longitude and depth $(0-2000 \mathrm{~m})$ along the OVIDE track as estimated from hydrographic surveys (OVIDE 2002OVIDE 2010). The 2002-2010 mean summer temperature (c) and velocity (d) fields estimated from AVISO and ISAS data sets as explained in Section 4.1. The color shadings in (a) and (b) are the same as in (c) and (d). The heavy line in (a)-(d) is the $\sigma_{1}=32.14$ isopycnal corresponding to the mean $\sigma_{\mathrm{MOC}}$ computed from OVIDE hydrography (black) and ISAS (blue). (e) Difference in the depth of $\sigma_{\mathrm{MOC}}(\mathrm{m})$ between the two estimates; the difference is negative when the OVIDE hydrography-derived isopycnal is deeper than that obtained from ISAS. (f) Cumulative sum of the 
2002-2010 mean summer transport in the $\mathrm{MOC}_{\sigma}$ upper limb from the OVIDE inversions (black line) and from the reconstruction based on the AVISO and ISAS data set (blue line). The differences in bathymetry close to the Greenland slope between a-b and c-d are due to the different spatial resolutions of the data sets.

Figure 8: Meridional overturning streamfunctions for FOUREX 1997 and OVIDE 2006 (yellow and black continuous lines, respectively) compared with the streamfunctions reconstructed from AVISO and ISAS data sets (see Section 4.1) and averaged over a three month period centered at the months of the FOUREX 1997 and OVIDE 2006 cruises (yellow and black dotted line, respectively). The cyan curves figure the averages over the six OVIDE cruises. The vertical coordinate is $\sigma_{1}\left(\mathrm{~kg} \mathrm{~m}^{-3}\right)$. Note that the plot is a zoom on the 31-32.7 density range and, contrary to Figure 3, does not show the lower densities.

Figure 9: Intra-annual variability of the $\mathrm{MOC}_{\sigma}$ (black line, grey error bar) as computed for 19932010 from AVISO, ISAS and NCEP data sets (see Section 4.1). The intra-annual variability of the Ekman transport and the associated error bars are plotted in red. The dash-dotted line is the intraannual variability of the geostrophic component of $\mathrm{MOC}_{\sigma}$. All transports are in Sv. 


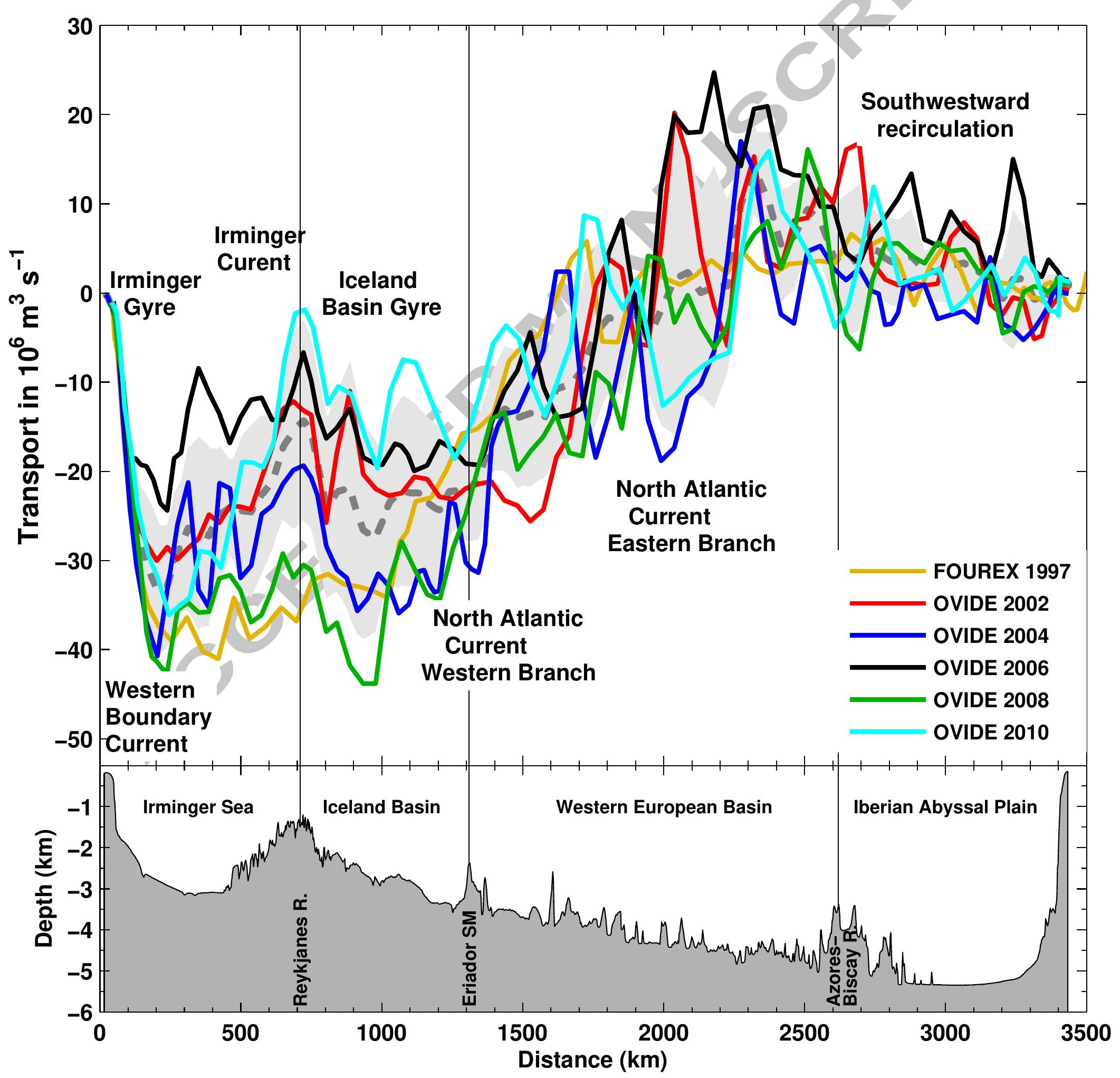




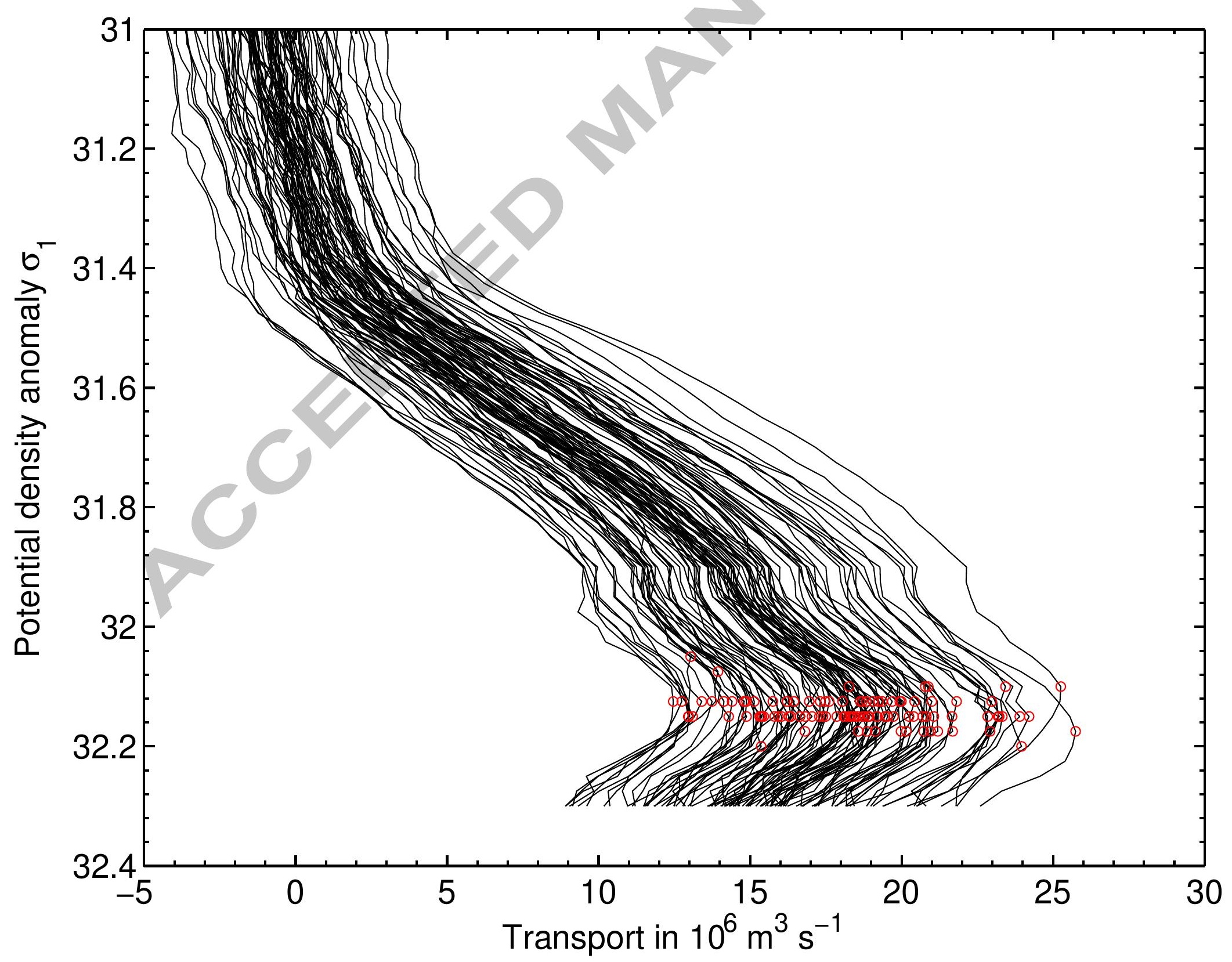


Figure 6

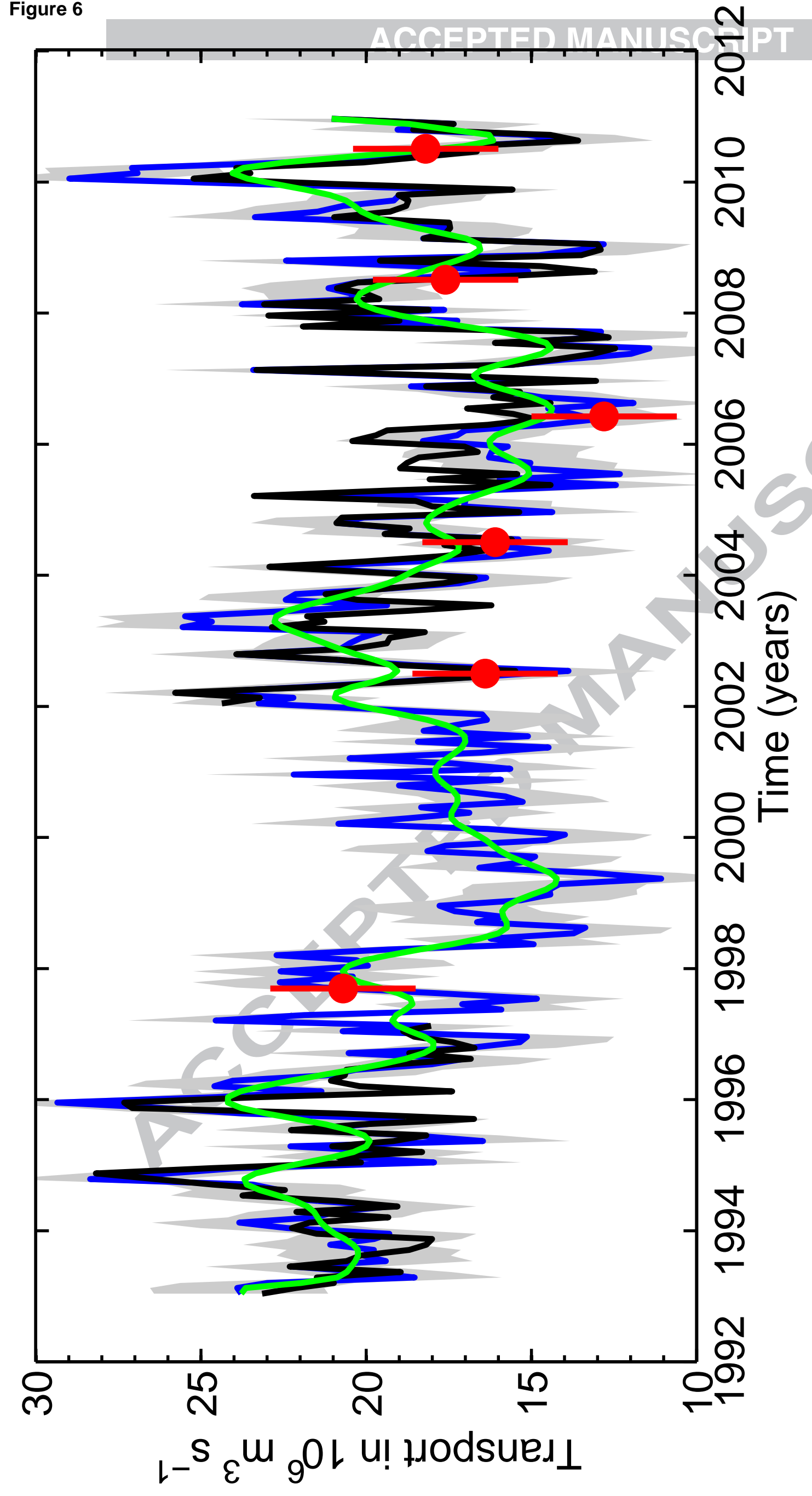




\section{ACCEPTED MANUSCRIPT}
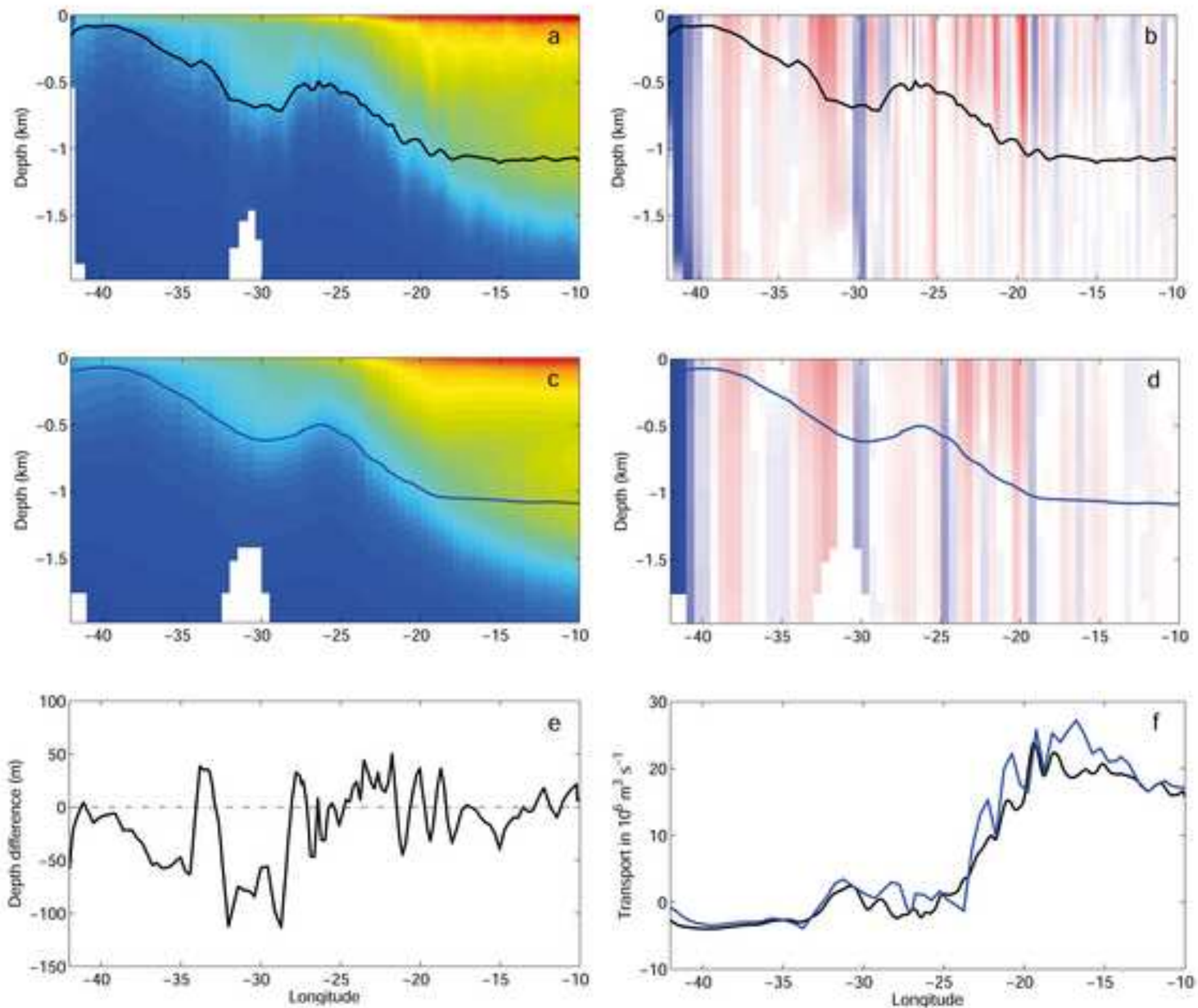


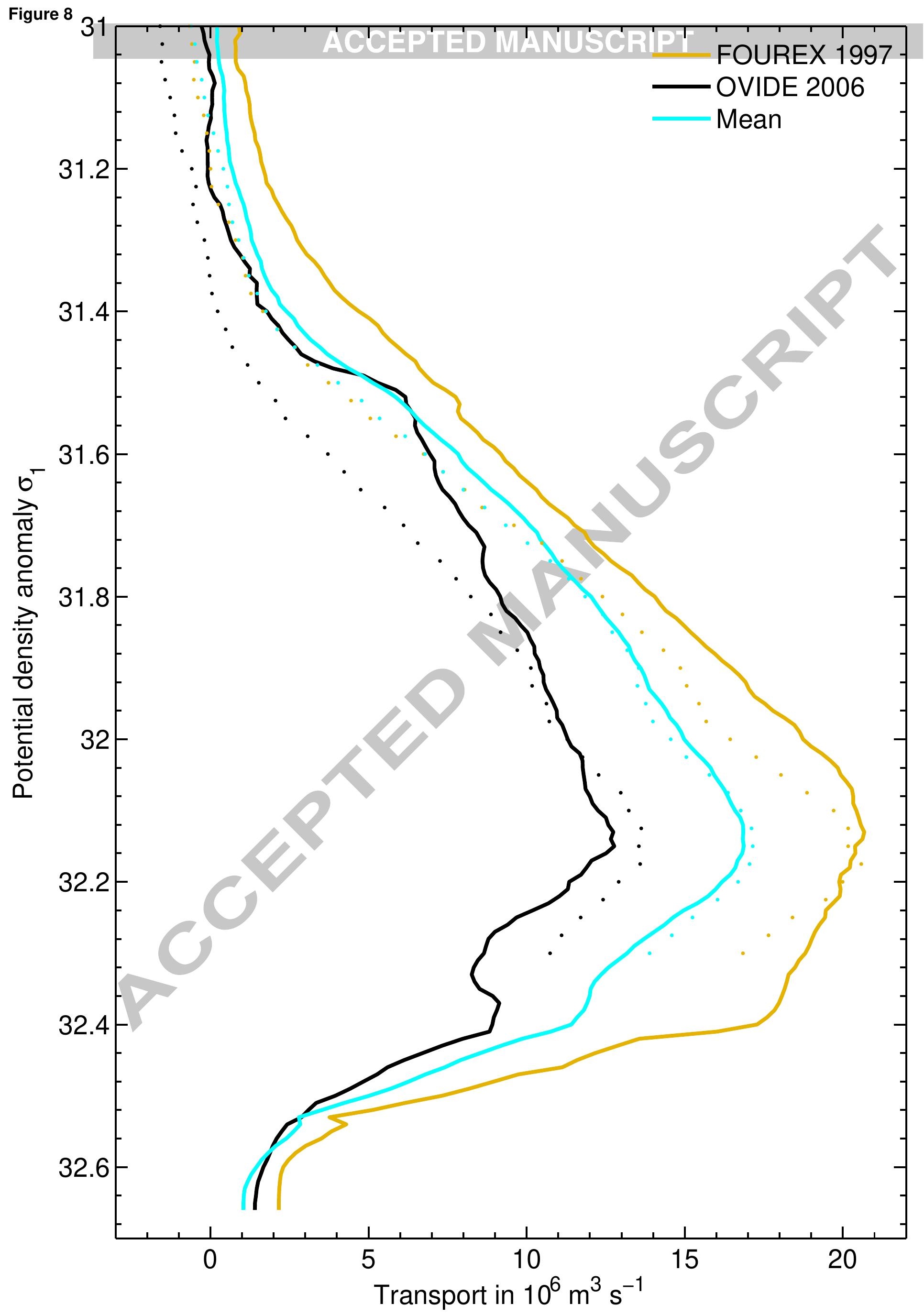


Figure 9

\section{ACCEPTED MANUSCRIPT}

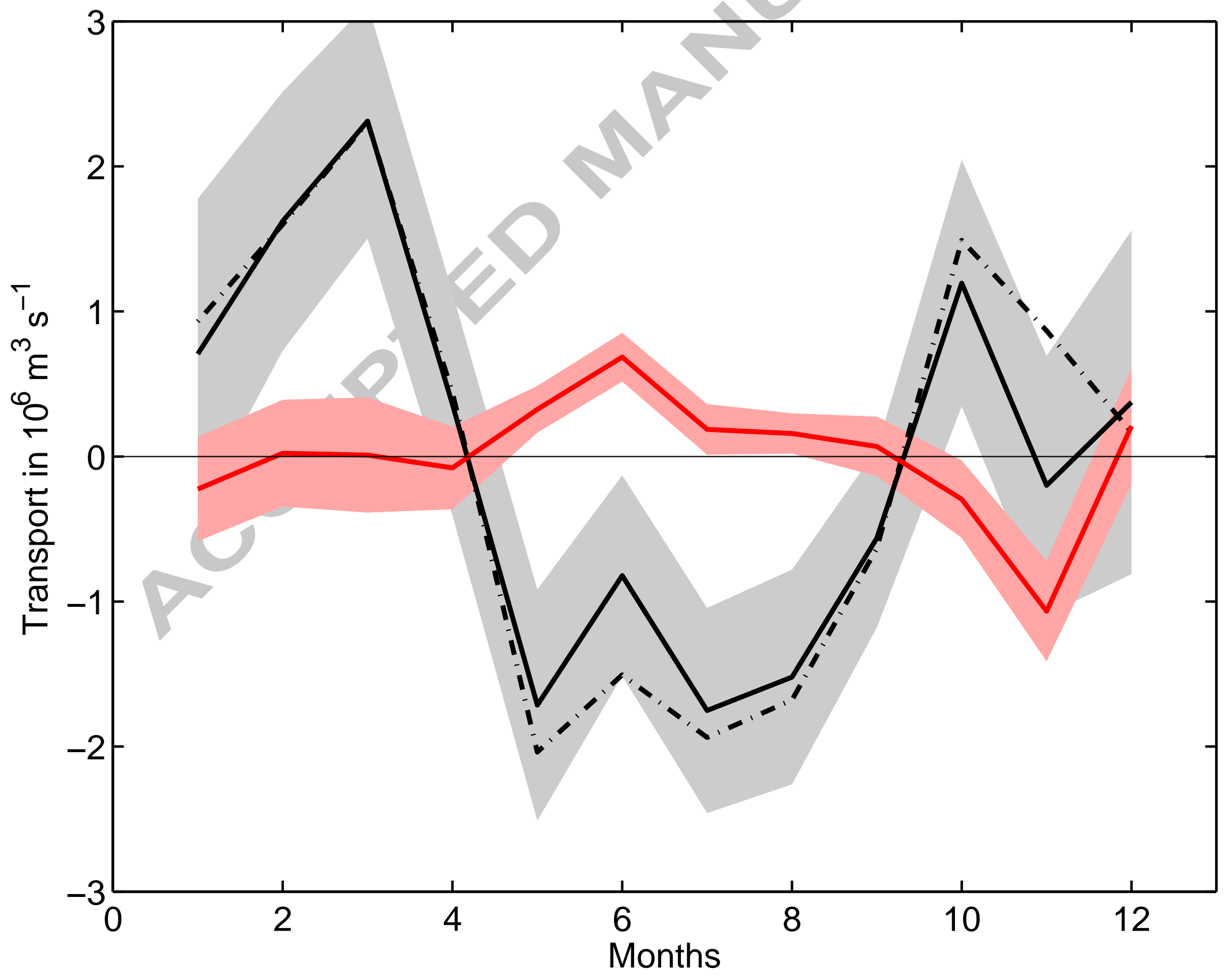


Table 1. Hydrographic cruises.

\begin{tabular}{llll}
\hline Cruise Name & Month/Year & Vessel & Reference \\
\hline FOUREX 1997 & $08-09 / 1997$ & R/V Discovery & Alvarez et al. (2002) \\
OVIDE 2002 & $06-07 / 2002$ & N/O Thalassa & Lherminier et al. (2007) \\
OVIDE 2004 & $06-07 / 2004$ & N/O Thalassa & Lherminier et al. (2010) \\
OVIDE 2006 & $05-06 / 2006$ & R/V Maria S. Merian & Gourcuff et al. (2011) \\
OVIDE 2008 & $06-07 / 2008$ & N/O Thalassa & \\
OVIDE 2010 & $06-07 / 2010$ & N/O Thalassa & \\
\hline
\end{tabular}


Table 2. Magnitudes of the $\mathrm{MOC}_{\sigma}$ and $\mathrm{MOC}_{\sigma}$ upper limb, density of the maximum of the overturning streamfunction $\left(\sigma_{\mathrm{MOC}}\right)$, net volume transport across the section (Net transport), magnitude of the $\mathrm{MOC}_{\mathrm{z}}$, heat flux (HF), for the 6 repeats of the Ovide hydrographic section. Transports are in Sv, HF in PW. Estimation errors are 2.4 Sv on $\mathrm{MOC}_{\sigma}$ and $0.05 \mathrm{PW}$ on $\mathrm{HF}$. The mean values are also reported.

\begin{tabular}{lcccccc}
\hline & MOC $_{\sigma}$ & $\begin{array}{c}\mathrm{MOC}_{\sigma} \\
\text { upper limb }\end{array}$ & $\sigma_{\mathrm{MOC}}$ & Net transport & $\mathrm{MOC}_{\mathrm{z}}$ & $\mathrm{HF}$ \\
& $\mathrm{Sv}$ & $\mathrm{Sv}$ & $\mathrm{kg} \mathrm{m}^{-3}$ & $\mathrm{~Sv}$ & $\mathrm{~Sv}$ & $\mathrm{PW}$ \\
\hline FOUREX 1997 & 18.5 & 20.7 & 32.13 & 2.2 & 15.0 & 0.70 \\
OVIDE 2002 & 16.2 & 16.4 & 32.20 & 0.2 & 8.7 & 0.45 \\
OVIDE 2004 & 16.4 & 16.1 & 32.10 & -0.3 & 8.7 & 0.51 \\
OVIDE 2006 & 11.4 & 12.8 & 32.14 & 1.4 & 9.2 & 0.29 \\
OVIDE 2008 & 16.5 & 17.6 & 32.14 & 1.1 & 7.4 & 0.50 \\
OVIDE 2010 & 16.9 & 18.2 & 32.15 & 1.3 & 14.0 & 0.60 \\
Mean & 16.0 & 17.0 & 32.14 & 1.0 & 10.5 & 0.51 \\
\hline
\end{tabular}


Table 3. Decomposition of $\mathrm{HF}(\mathrm{PW}) . \mathrm{HF}_{\mathrm{dia}}$ and $\mathrm{HF}_{\text {iso }}$ are the diapycnal and isopycnal components of $\mathrm{HF} ; \mathrm{HF}_{\text {net }}$ is the heat flux component associated with the net volume transport across the section. The estimation error on $\mathrm{HF}$ is $0.05 \mathrm{PW} . \Delta \theta$ is the temperature difference in ${ }^{\circ} \mathrm{C}$ between the upper and lower limbs of the $\mathrm{MOC}_{\sigma}$ and $\rho c_{p} \Delta \theta \mathrm{MOC}_{\sigma}$ is a linearization of $\mathrm{HF}_{\text {dia. }}$. The mean values are also indicated.

\begin{tabular}{|c|c|c|c|c|c|c|}
\hline & $\mathrm{HF}$ & $\mathrm{HF}_{\mathrm{dia}}$ & $\mathrm{HF}_{\text {iso }}$ & $\mathrm{HF}_{\text {net }}$ & $\Delta \theta$ & $\rho c_{p} \Delta \theta \mathrm{MOC}_{\sigma}$ \\
\hline & \multicolumn{4}{|c|}{ PW } & ${ }^{\circ} \mathrm{C}$ & PW \\
\hline FOUREX 1997 & 0.70 & 0.61 & 0.05 & 0.04 & & 0.55 \\
\hline OVIDE 2002 & 0.45 & 0.41 & 0.03 & 0.01 & 6.59 & 0.44 \\
\hline OVIDE 2004 & 0.51 & 0.44 & 0.08 & -0.01 & 6.91 & 0.47 \\
\hline OVIDE 2006 & 0.29 & 0.34 & -0.07 & 0.02 & 6.81 & 0.32 \\
\hline OVIDE 2008 & 0.50 & 0.47 & 0.01 & 0.03 & 6.84 & 0.46 \\
\hline OVIDE 2010 & 0.60 & 0.53 & 0.05 & 0.02 & 6.80 & 0.47 \\
\hline Mean & 0.51 & 0.46 & 0.03 & 0.02 & 6.87 & 0.45 \\
\hline
\end{tabular}




\section{Highlights}

We analyze the 1993-2010 variability of the $\mathrm{MOC}_{\sigma}$ at the Greenland-Portugal OVIDE line We show that the $\mathrm{MOC}_{\sigma}$ can be monitored using Altimetry and Argo

The $\mathrm{MOC}_{\sigma}$ varies on monthly to decadal time scales

The $\mathrm{MOC}_{\sigma}$ shows an overall decline of $2.5 \pm 1.4 \mathrm{~Sv}$ between 1993 and 2010

The heat flux is linearly related to the $\mathrm{MOC}_{\sigma}$ magnitude 